\title{
Evidence Of Recent Recruitment In The Ocean Quahog Arctica Islandica In The Mid-Atlantic Bight
}

\author{
EN Powell
}

Roger L. Mann

Virginia Institute of Marine Science

Follow this and additional works at: https://scholarworks.wm.edu/vimsarticles

Part of the Marine Biology Commons

\section{Recommended Citation}

Powell, EN and Mann, Roger L., "Evidence Of Recent Recruitment In The Ocean Quahog Arctica Islandica In The Mid-Atlantic Bight" (2005). VIMS Articles. 457.

https://scholarworks.wm.edu/vimsarticles/457 


\title{
EVIDENCE OF RECENT RECRUITMENT IN THE OCEAN QUAHOG ARCTICA ISLANDICA IN THE MID-ATLANTIC BIGHT
}

\author{
ERIC N. POWELL ${ }^{1}$ AND ROGER MANN ${ }^{2}$ \\ ${ }^{1}$ Haskin Shellfish Research Laboratory, Rutgers University, 6959 Miller Ave., Port Norris, New Jersey \\ 08349; ${ }^{2}$ Virginia Institute of Marine Sciences, College of William \& Mary, \\ Gloucester Point, Virginia 23062
}

\begin{abstract}
We report results of a survey explicitly focused on ocean quahog recruitment in the Mid-Atlantic Bight. The recruitment survey resampled all NMFS survey sites south of Hudson Canyon and a selection of sites north and east of Hudson Canyon off the Long Island coast over the entire depth range of this species with the exception of the most inshore reaches off Long Island. More ocean quahogs were encountered, on a per tow basis, in the vicinity of and north of Hudson Canyon. The proportion of recruits in the size-frequency distribution was higher in the south and the most recent recruitment events were concentrated there. Analysis of the 104 size-frequency distributions delineated regions of recent recruitment, areas that have not seen significant recruitment for many decades and areas that received heavy recruitment some decades previously but not recently. Overall, the survey suggests that three regionally distinctive processes determine the size-frequency distributions of ocean quahog assemblages and recruitment therein. The area northeast of Hudson Canyon is unique in the regionally extensive uniformity of size-frequency distributions among sampled assemblages, the near absence of recent recruitment and the presence of large numbers of older recruits, $65-80 \mathrm{~mm}$ in size. The inshore (by ocean quahog standards) area off New Jersey is unique in the dominant presence of the largest size classes of ocean quahogs and the remarkable absence of significant recruitment over an extraordinary time span. The area south of $39^{\circ} \mathrm{N}$ is unique in the widespread presence of relatively young recruits, including some animals with ages within the time span of the present fishery. Recruitment events in ocean quahog populations, although rare in the sense of occurring only once in a score or two of years, are frequent in the context of the +200 -year life span of this species, yet also rare in the context of stock survey timing and fishery dynamics. This study strongly supports the assumption that long-lived species recruit successfully only rarely when at carrying capacity. This study also suggests that the history of recruitment over the last perhaps two-score years, revealed by this survey, may be a poor measure of the recruitment dynamics to be anticipated over the next two-score years when the population abundance is reduced to what is anticipated to approximate the biomass at maximum sustainable yield. Given the long time span required for ocean quahogs to grow to fishable size, a substantive disequilibrium may exist between the recruitment anticipated from the relationship of adult biomass to carrying capacity and the contemporaneous number of recruits for minimally $20 \mathrm{y}$ after adult abundance is reduced from circa-1980 carrying capacity to biomass, maximum sustainable yield.
\end{abstract}

KEY WORDS: recruitment, ocean quahog, Arctica, fisheries management, size-frequency distribution

\section{INTRODUCTION}

The bivalve Arctica islandica, known commonly by the appellation ocean quahog, is a widely distributed biomass dominant on the central and outer shelf of the Mid-Atlantic Bight (Cargnelli et al. 1999, NEFSC 1998, 2000). A fishery sustaining an annual catch of $\sim 4.5$ million bushels has existed since the early 1980s (NEFSC 1998, Cargnelli et al. 1999), when the stock was considered to be at carrying capacity (NEFSC 1998). Most recent estimates indicate that the stock is presently near $80 \%$ of carrying capacity after 2 decades of fishing (NEFSC 2000, NEFSC 2004). Therefore, fishing has slowly reduced stock abundance.

The National Marine Fisheries Service (NMFS) conducts a stock assessment survey for ocean quahogs approximately every 2-3 y and has done so since about 1978. Early in the survey time series, little recruitment was noted (Kennish et al. 1994, Lewis et al. 2001). Quahogs are long-lived animals (Ropes \& Jearld 1987, Kennish \& Lutz 1995, Thórarinsdóttir \& Steingrímsson 2000, Witbaard et al. 1994) and, as a consequence, might be expected to recruit rarely in significant numbers. Moreover, some species at carrying capacity might not be expected to recruit in large numbers (Hilborn \& Walters 1992, May et al. 1978). Therefore, the limited evidence of recruitment from early stock assessment surveys was not surprising. However, beginning in the mid1980s, the fishery began to significantly reduce stock abundance off the Delmarva

\footnotetext{
*Corresponding author. E-mail: eric@ @hsr__rutgers.edu
}

Peninsula (NEFSC 1998, NEFSC 2000). Over the next decade, fishing slowly expanded north and east across the outer New Jersey shelf, then off Long Island and finally into southern New England. One might anticipate, with the fishing down of local populations, that the rate of recruitment would rise, and evidence of recruitment consequently would appear.

This expectation of increased recruitment follows from the Schaefer model of the population dynamics of fished populations (Hilborn \& Walters 1992) that relates biomass, $B$, the intrinsic rate of natural increase, $r$, carrying capacity, $K$ and fishing, $C: d B / d t=$ $r B(1-B / K)-C$. The Schaefer model equates surplus production, the first term on the right-hand side, with catch, the second term, when no change in biomass occurs: $d B / d t=0$. Surplus production approaches zero at low biomass levels as population fecundity is limited by broodstock availability and at carrying capacity in which population fecundity or recruitment are limited by densitydependent compensatory processes. In general, surplus production is maximal when biomass, $B$, is half that of carrying capacity: $B_{m s y}$ $=K / 2$ (e.g., Hilborn \& Walters 1992, May et al. 1978). $B_{m s y}$ is referred to as biomass at maximum sustainable yield. Simultaneously with the development of the ocean quahog fishery was the development of more rigorous approaches to fisheries management in the United States that culminated in the most recent authorization of the Magnuson-Stevens Fishery Conservation and Management Act (Anonymous 1996) that governs the management of United States fisheries in federal waters. This statute requires management of fisheries resources at maximum sustainable yield, $m s y$ and, consequently, managers seek to regulate population 
biomass at $B_{m s y}$. Ocean quahogs are believed to have been at or near carrying capacity circa 1980 . Since then, the fishery reduced biomass to about $80 \%$ of carrying capacity (NEFSC 2004). As the ocean quahog population continues to be fished down to $B_{m s y}$, the expectation of increased recruitment rises and, consequently, accurate estimates of the rate of recruitment become more important in managing the ocean quahog fishery.

The NMFS survey dredge, like most commercial dredges, does not quantitatively catch the smaller size classes. Thus, the sampling gear may not adequately detect recruitment events until the recruits are quite old. Despite this limitation, recently, evidence of quahog recruitment on Georges Bank has been reported from NMFS survey samples (Lewis et al. 2001). Curiously, and perhaps perversely, this is also a region of the northeastern Atlantic that has not been routinely fished. Inasmuch as these observations provide a trend counter to the carrying capacity model and recruitment in the more heavily fished southern populations seemingly remains low, evidence of quahog recruitment continues to be elusive and intuitively abstruse.

The limited information on quahog recruitment is primarily a function of the minimum size caught quantitatively by the survey dredge. Although dredge efficiency is inherently less than $100 \%$ (NEFSC 1998, NEFSC 2000; see also Ragnarsson \& Thórarinsdóttir 2002), the NMFS survey dredge (Smolowitz \& Nulk 1982) captures ocean quahogs from maximum size, $\sim 130 \mathrm{~mm}$, down to a size in the range of $70-75 \mathrm{~mm}$ with about equivalent catchability (NEFSC 1998, Lewis et al. 2001). A somewhat larger size range cut-off is typical for commercial dredges. Animals 75-mm long are already in the range of 40 or more years old (Murawski et al. 1982, Fritz 1991). $\dagger$ This is about twice the age of the fishery, so standard surveys cannot yet provide unequivocal evidence of recruitment that has occurred since fishing began, and the population was pulled slowly down from carrying capacity.

The purpose of this study is to implement a survey explicitly focused on ocean quahog recruitment in the Mid-Atlantic Bight. The survey targeted animals as small as $25 \mathrm{~mm}$. Animals in the 25-75 mm size range can be expected to have ages in the range of about $+6-40$ years and, thus, some of these clams may have recruited since the inception of the fishery circa 1980. As importantly, many of them will recruit to the fishery over the next score or so years and this recruitment must balance the anticipated fishing mortality at $B_{m s y}$. $B_{m s y}$ should be reached in another approximately $20 \mathrm{y}$. Put another way, when $B_{m s y}$ is reached, the recruits necessary to prevent population biomass from dropping below $B_{m s y}$ will be those in evidence today, whereas the greater number of recruits anticipated to be produced by a population at $B_{m s y}$ will require a further score or more years to impact the fishery. This disequilibrium is one of the most serious problems that will face managers in the coming decades.

$\dagger$ The reader is cautioned that we have relied on age-size relationships published in Murawski et al. (1982) and Fritz (1991) as guides to the approximate ages of ocean quahogs in various size classes. We do so primarily to couch processes in order of occurrence and to evoke some appreciation of time scale. We make no claim as to the accuracy of the dating of specific events; only that specific events did occur and that these can be ordered in time, and we point out that Lewis et al. (2001) and Sager and Sammler (1983) have reported more rapid growth rates on Georges Bank that would compress by about $50 \%$ the age ranges referred to throughout this contribution.

\section{METHODS}

\section{Survey Approach}

The NMFS conducted a survey of ocean quahogs in the summer of 2002 (NEFSC 2004). The recruitment survey resampled a subset of NMFS survey sites during September 14 to 19, 2002. This subset included all sites yielding live ocean quahogs in the 2002 NMFS survey south of Hudson Canyon and a selection of sites north and east of Hudson Canyon off the Long Island coast nearly as far east as Montauk, New York. Sampling covered the entire depth range of this species over this geographic region with the exception of the most inshore reaches off Long Island. The F/V Christie, homeport Ocean City, Maryland, was used as the survey vessel. Sampling sites are shown in Figure 1.

To catch ocean quahogs $<75 \mathrm{~mm}$, a number of modifications were made to the vessel. A typical quahog dredge has a bar spacing too large to catch ocean quahogs in the desired size range. Clams caught by the dredge are dropped into a hopper after dredge retrieval. From the hopper, the clams move up a belt and then across a set of rollers or over a shaker with bar spacings that permit efficient sorting of small material, single shells, undersized clams, and most bycatch from clams of market size. Clams are then moved by belt to cages in the hold. To conduct the recruitment survey, 3 modifications were made to this system. (1) The dredge was lined with chicken wire of 2.54-cm diameter. Clams $\geq 25 \mathrm{~mm}$ could not pass through this mesh. The chicken wire was affixed to the bars of the dredge by metal ties and cable ties. The metal ties worked best, but the cable ties held up for a surprisingly long time. The dredge was lined with chicken wire on both sides, the bottom and top, the door at the back of the dredge and the angled lower portion of the dredge just behind the knife. Thus, the entire dredge was lined. The integrity of the chicken wire was examined after each tow and occasional repairs were made. Repairs were rarely required except for the chicken wire stretched over the front end of the dredge just behind the knife. It was necessary to catch this wire

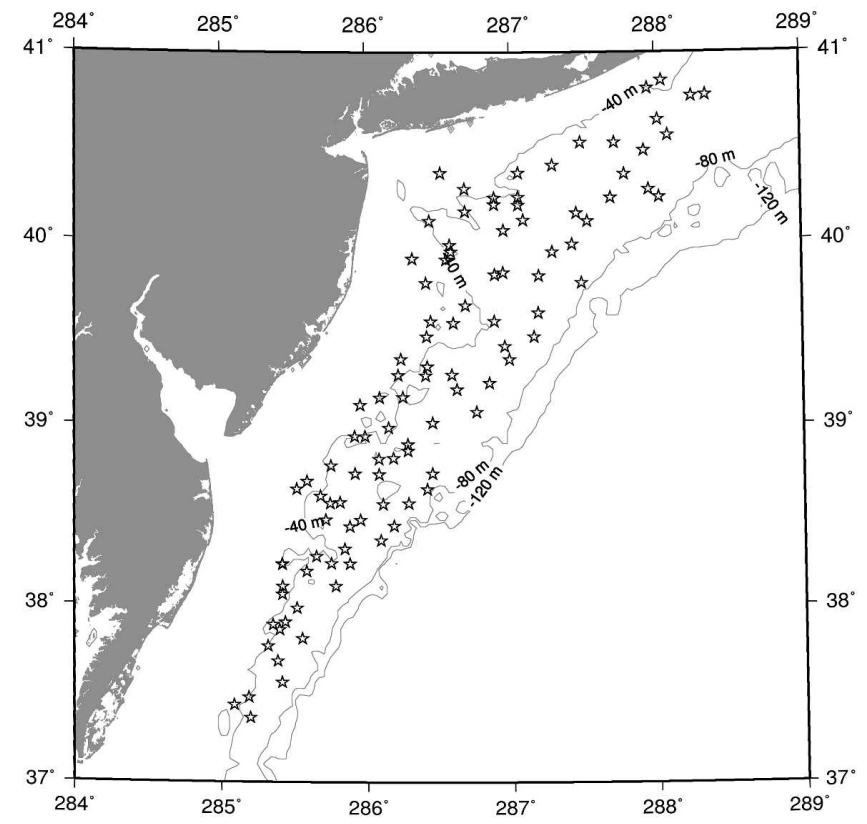

Figure 1. Location of sampling stations for the ocean quahog recruitment survey. 
between two knife blades to prevent it from pulling away from the knife. (2) The shaker was bypassed by means of a metal shoot affixed to the shaker and extending from the hopper belt to the belt running along the deck to the hold. This metal shoot permitted the entire contents of the dredge to be moved from the hopper to the belt on the deck. (3) The water jets that normally are oriented to wash material through the shaker were reoriented to wash material down the shoot to the belt on the deck.

A trial run was conducted on April 20, 2002. Tows of various durations from $30 \mathrm{sec}$ to $2 \mathrm{~min}$ were conducted. Knife depths of $5.1 \mathrm{~cm}$ to $10.2 \mathrm{~cm}$ were examined. Tow speed was maintained approximately at the industry standard of $5.6 \mathrm{~km} \mathrm{hr}^{-1}$. Test tows revealed that the dredge could be nearly filled to capacity with material in about $2 \mathrm{~min}$ on bottom. This quantity of material could not be efficiently processed onboard. Consequently, tows were timed to be about $1 \mathrm{~min}$ on bottom. Catches using a knife blade depth of $5.1 \mathrm{~cm}$ were obviously smaller than for deeper blade depths. A blade depth of 7.6-10.2 cm is typical for industry vessels. A 1-min tow with a knife blade depth of $10.2 \mathrm{~cm}$ could be processed onboard. Thus, this towing procedure was adopted for all survey tows.

Swept areas can be calculated routinely from the time on bottom and the width of the dredge (NEFSC 2000), $254 \mathrm{~cm}$ in the case of the F/V Christie. For tows of 3 min or more, such swept areas are accurate because the degree of uncertainty as to the time on and off bottom does not exceed $10 \mathrm{sec}$, less than $10 \%$ of total tow time. However, for a 1-min tow, the degree of uncertainty is proportionately much larger. Thus, quantification of catch by swept area was not attempted. For this reason, most analyses were conducted after standardization of catch to 100 clams tow $^{-1}$. Numbers per $\mathrm{m}^{2}$ are not reported. However, because all tows were conducted in a similar manner, we, in a few analyses, assume that time on bottom was similar for all tows. $\$$

Processing of a dredge haul was conducted as follows. The vessel steamed to the designated point. The dredge was deployed and then retrieved after $1 \mathrm{~min}$ on the bottom. The contents were dumped into the hopper. Hopper and deck belt speed were then set so that the material coming out of the hopper could be efficiently sorted by two individuals while it traversed the deck belt and finally was flushed back overboard. Sorting efficiency was checked by setting belt speed such that the first sorter picked out nearly all of the ocean quahogs, leaving the second sorter little to find. If the second sorter began to find more than the occasional clam, the belt speed was lowered, permitting the first sorter more time to sort through the load. Sorting time for a typical dredge haul varied between $30 \mathrm{~min}$ and $1 \mathrm{~h}$. Teaming time between stations was also about this long, so that processing on deck was nearly continuous during the cruise.

All ocean quahogs regardless of size were sorted out. In most cases all ocean quahogs were measured to the nearest $1 \mathrm{~mm}$ in longest dimension using a measuring board. In a few tows, the total number of quahogs exceeded 300 , even in a 1 min tow. In these cases the larger quahogs exceeding $70-80 \mathrm{~mm}$, depending on

\footnotetext{
$\ddagger$ In passing, as all but a few of our sites were NMFS survey sites, and because our dredge and the NMFS dredge were quantitative for clams $>80$ $\mathrm{mm}$, the number of clams caught below $80 \mathrm{~mm}$ might be quantitated using the ratio of $\geq 80$-mm clams in our tows and those in the 2002 NMFS survey catch. The NMFS survey is quantitated using dredge depletion experiments to estimate dredge efficiency (NEFSC, 1998, 2000, 2004).
}

the tow, were subsampled. In all cases, all quahogs $<70 \mathrm{~mm}$ were measured.

\section{Data Analysis}

Size-frequency distributions were constructed in 1-mm intervals. For convenience, in some figures, these data have been collapsed into 5-mm size classes.

To examine the relationships in size-frequency distribution between sites, a principal component analysis (PCA) was run. For convenience, in this case ocean quahogs were lumped into 5-mm categories. Size-frequencies were than standardized to the number in each 5-mm size class per 100 individuals caught in the tow, thereby giving each tow equal weight. PCA was conducted with orthogonal rotation on data further standardized to a mean of zero and variance of 1 .

Statistical analyses focused on ANCOVA using factor scores as the dependent variables, the total number of clams caught per tow as the covariate, and depth zone and latitudinal zone as main effects. Sampled depths were allocated to 1 of 3 depth zones for these analyses: $<43 \mathrm{~m}, 43-55 \mathrm{~m}$ and $>55 \mathrm{~m}$. This depth zonation allocated a relatively even distribution of stations into each zone: 29,30 and 45 respectively. Stations were allocated to 4 geographic zones based on degree of north latitude: $>40^{\circ}, 39^{\circ}$ to $40^{\circ}, 38^{\circ}$ to $39^{\circ}$ and $<38^{\circ}$. This zonation also allocated stations relatively evenly: 27, 32, 34 and 11 respectively. The lowermost zone was somewhat underrepresented, but was important to be maintained separate because it encompasses an area off the Delmarva Peninsula that received significant fishing pressure early in the ocean quahog fishery's history, during the mid-1980s and as it marks the southernmost extension of the geographic range (Dahlgren et al. 2000). A posteriori least-square means tests were used to identify significant components within the ANCOVA.

We caution the reader concerning the use of total catch as the covariate. The large time differential between the time of collection and the time of settlement suggests that one should use a total abundance of prior decades. These data are not available. As a consequence, the assumption is made that adult abundance has changed relatively little between the time of collection and the time of settlement. Over the whole stock, this assumption is reasonable, because present-day biomass is about $80 \%$ of that present circa-1980 (NEFSC 2004). However, in some areas, such as Delmarva, this assumption is much less valid. Nevertheless, an indication of a relationship between recruitment and adult abundance can only be obtained in this way.

\section{RESULTS}

\section{Abundance}

The number of ocean quahogs caught in a 1-min tow varied from 0-1061 (Fig. 2). Larger catches occurred farther north. Catches were significantly higher north of $40^{\circ} \mathrm{N}$ latitude than farther south (Table 1). Catches were also significantly higher at depths deeper than $43 \mathrm{~m}$ (Table 1). When only the smaller portion of the size-frequency distribution was assessed, those clams $<80$ $\mathrm{mm}$, catches varied by geographic region, but no longer by depth (Table 1). Many more small quahogs were caught north of $40^{\circ} \mathrm{N}$ latitude than in regions farther south (Table 1).

Proportionately more clams $<80 \mathrm{~mm}$ were caught south of $38^{\circ} \mathrm{N}$ latitude, however (Table 1). Proportionately fewer clams were caught between $38^{\circ} \mathrm{N}$ and $39^{\circ} \mathrm{N}$ than elsewhere. Interestingly, 


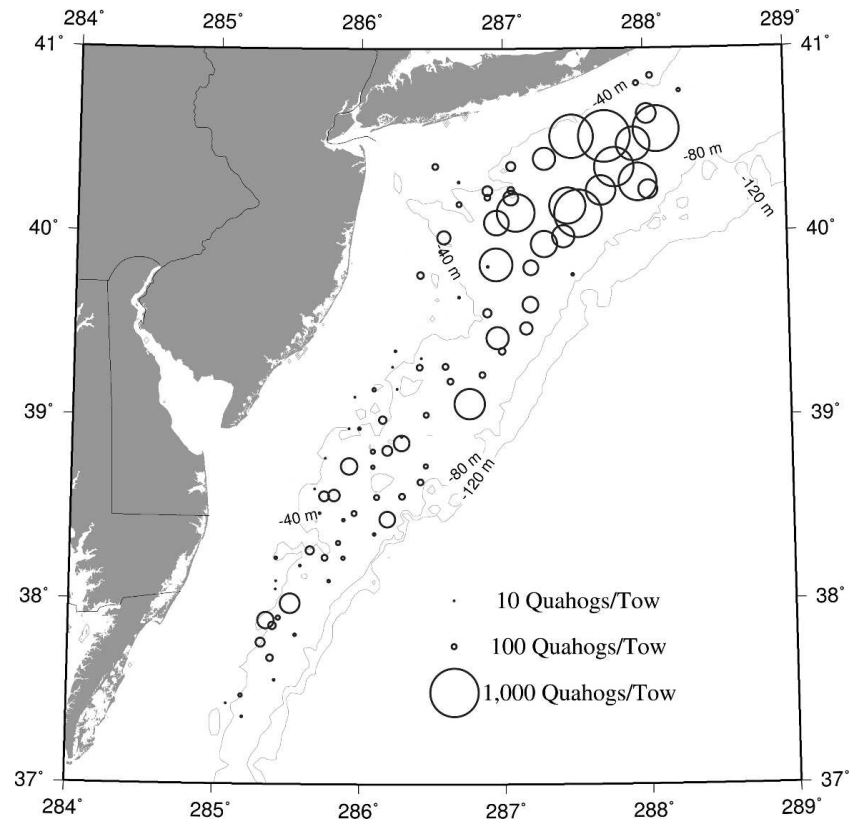

Figure 2. Numbers of ocean quahogs, Arctica islandica, captured in a 1-min tow during the recruitment survey.

the proportion of small clams was higher south of $38^{\circ} \mathrm{N}$ latitude than north of $39^{\circ} \mathrm{N}$, even though the abundance of small clams was highest in the more northern regions (Table 1). The deeper depth zone, $>55 \mathrm{~m}$, had proportionately more small clams (Table 1 ).

\section{End-member Size-frequency Distributions}

Characteristic or end-member size-frequency distributions were constructed by cumulating the size-frequency distributions for ocean quahog assemblages from stations with PCA factor scores exceeding 1.0. To accomplish this, PCA analysis was conducted using the entire size-frequency distribution for all samples, after standardization to weight each sample equally. The first four PCA factors determining the four principal end-member sizefrequency distributions accounted for $58 \%$ of the total variation. Each of these PCA factors was determined primarily by the correlations between a set of the twenty-four 5-mm size classes that served as the database for the PCA. Those stations with PCA scores exceeding 1.0 for a given PCA factor represented stations with size-frequency distributions dominated by the size classes determining that PCA axis. By this means, the complex of over 100 individual size frequencies could be interpreted in terms of a few dominant size-frequency patterns.

A series of the smallest size classes, between 16 and $35 \mathrm{~mm}$ and between 41 and $45 \mathrm{~mm}$, loaded most heavily on Factor 1. The summary size-frequency distribution cumulating all stations achieving a factor score exceeding 1.0 for Factor 1 is shown in Figure 3. This size-frequency distribution has 2 modes. Stations with high Factor 1 scores contain a substantial fraction of small individuals, less than $60 \mathrm{~mm}$ in size, and a second mode comprising individuals $86-100 \mathrm{~mm}$ in size.

The summary size-frequency distribution for assemblages with Factor 2 scores exceeding 1.0 shows a single mode in the range 66-95 mm (Fig. 3). Ocean quahogs in the size range $66-80 \mathrm{~mm}$ were primary determinants of Factor 2 scores and account for most of the single mode in the size-frequency diagram shown in Figure 3. It is interesting that this single mode falls between the two modes present in the end-member size-frequency distribution for ocean quahog assemblages scoring highest for Factor 1 (Fig. 3).

The largest ocean quahog size classes, 106-130 mm, loaded most heavily on Factor 3. Assemblages scoring $>1.0$ on this factor had a single primary mode in their summary size-frequency distribution, between $96 \mathrm{~mm}$ and $130 \mathrm{~mm}$ (Fig. 4). Thus, the first 3

TABLE 1.

Results of ANOVA analysis using as the dependent variable the number of clams caught per tow. This analysis assumes an equivalent swept area for each tow. This assumption is further discussed in the Methods section. Depth zones and geographic regions are defined in the Methods section. Ratio is the fraction of clams $<80 \mathbf{~ m m}$. Results of least-square means tests are shown for significant main effects. - , not significant at $\alpha=0.05$. *, interaction term.

\begin{tabular}{|c|c|c|c|c|c|c|}
\hline & & \multicolumn{2}{|c|}{ Sizes $<80 \mathrm{~mm}$} & All Size Classes & \multicolumn{2}{|c|}{ Ratio } \\
\hline \multicolumn{2}{|c|}{$\begin{array}{l}\text { Depth Zone } \\
\text { Geographic Region } \\
\text { Depth*Region }\end{array}$} & \multicolumn{2}{|c|}{ 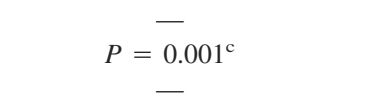 } & $\begin{array}{c}P=0.028^{\mathrm{a}} \\
P<0.0001^{\mathrm{d}} \\
-\end{array}$ & \multicolumn{2}{|c|}{$\begin{aligned} P= & 0.018^{\mathrm{b}} \\
P= & 0.0032^{\mathrm{e}} \\
& -\end{aligned}$} \\
\hline (a) & $43-55 \mathrm{~m}$ & $<43 \mathrm{~m}$ & (c) & $39-40^{\circ}$ & $38-39^{\circ}$ & $<38^{\circ}$ \\
\hline $\begin{array}{l}>55 \mathrm{~m} \\
43-55 \mathrm{~m}\end{array}$ & - & $\begin{array}{l}P=0.025 \\
P=0.016\end{array}$ & $\begin{array}{l}>40^{\circ} \\
39-40^{\circ} \\
38-39^{\circ}\end{array}$ & $P=0.0013$ & $\begin{aligned} P= & 0.0002 \\
& -\end{aligned}$ & $\begin{aligned} P= & 0.0342 \\
& - \\
& -\end{aligned}$ \\
\hline (b) & $43-55 \mathrm{~m}$ & $<43 \mathrm{~m}$ & (d) & $39-40^{\circ}$ & $38-39^{\circ}$ & $<38^{\circ}$ \\
\hline \multirow[t]{3}{*}{$\begin{array}{l}>55 \mathrm{~m} \\
43-55 \mathrm{~m}\end{array}$} & $P=0.041$ & $\begin{aligned} P= & 0.0057 \\
& -\end{aligned}$ & $\begin{array}{l}>40^{\circ} \\
39-40^{\circ} \\
38-39^{\circ}\end{array}$ & $P=0.002$ & $\begin{array}{c}P=0.0001 \\
-\end{array}$ & $\begin{aligned} P= & 0.0025 \\
& - \\
& -\end{aligned}$ \\
\hline & & & (e) & $39-40^{\circ}$ & $38-39^{\circ}$ & $<38^{\circ}$ \\
\hline & & & $\begin{array}{l}>40^{\circ} \\
39-40^{\circ} \\
38-39^{\circ}\end{array}$ & - & $\begin{array}{l}P=0.005 \\
P=0.06\end{array}$ & $\begin{aligned} &- \\
& P=0.037 \\
& P=0.0011\end{aligned}$ \\
\hline
\end{tabular}



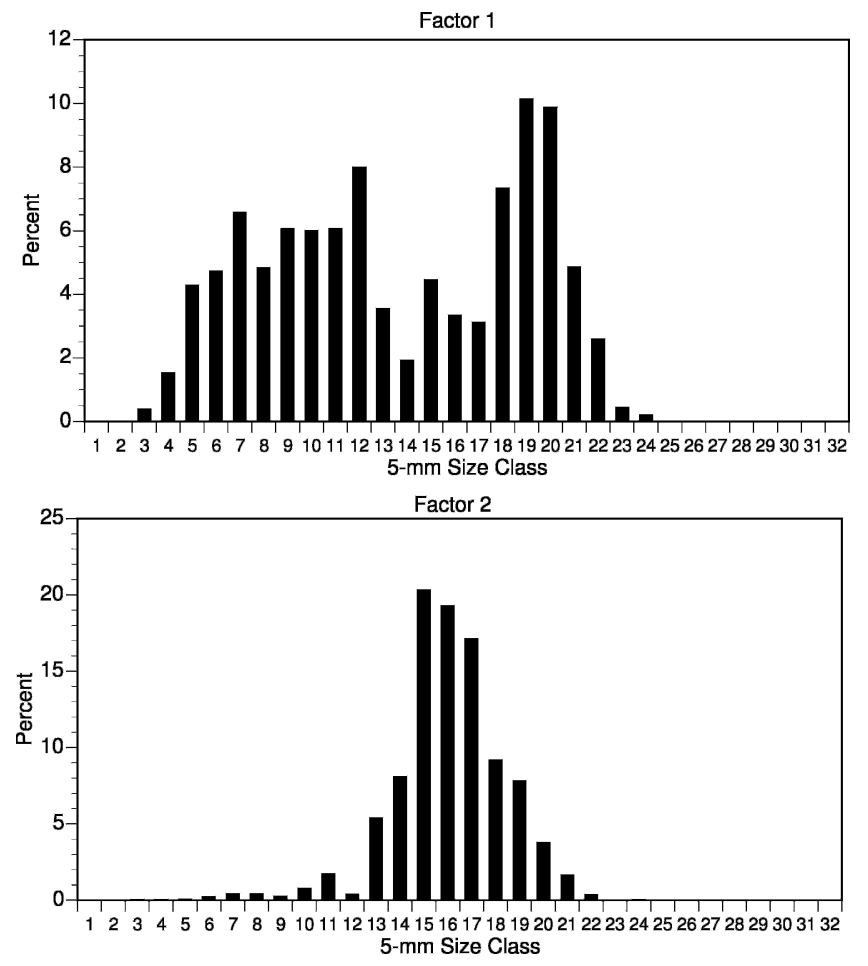

Figure 3. Summary size-frequency distributions for all stations with factor scores $>1.0$ for Factor 1 or Factor 2. Size classes are in 5-mm increments. Thus size class 1 represents clams $>0-5 \mathrm{~mm}$; size class 2 , clams $>$ 5-10 $\mathbf{m m}$, etc.

factors described ocean quahog assemblages composed of (1) small and moderately-large individuals; (2) medium-sized individuals and (3) large individuals.

The final and fourth factor was primarily defined by quahogs in the size range $36-40 \mathrm{~mm}, 51-55 \mathrm{~mm}$ and $61-65 \mathrm{~mm}$. The summary size-frequency distribution for assemblages scoring high on Factor 4 is similar to assemblages scoring high on Factor 1 (Fig. 4) in that it is bimodal and the upper mode contains individuals in the $86-100 \mathrm{~mm}$ size range; however, the smaller mode has proportionately more larger individuals, 36-65 $\mathrm{mm}$, and the sizefrequency distribution has proportionately fewer clams in the upper mode, $86-100 \mathrm{~mm}$.

Depiction in factor space of the 104 assemblages sampled demonstrates that the assemblages fall smoothly on a mixing curve defined by Factors 1, 2 and 3 with Factor 1 assemblages containing proportionately the smallest individuals and Factor 3 assemblages containing proportionately the largest individuals (Fig. 5). The extent to which assemblages fall off the Factor 2-Factor 3 axis describes the importance of small ocean quahogs in the assemblage's size-frequency distribution. The extent to which assemblages fall off the Factor 1-Factor 2 axis describes the importance of large ocean quahogs in the assemblage's size-frequency distribution. All assemblages represent some mixture of the three primary end-member size-frequency distributions, with the majority mixing Factor 1 with the moderately-sized animals of Factor 2 or with the large animals of Factor 3.

\section{Geographic Distribution and Statistical Relationships}

Assemblages scoring high on one of the four factors were not randomly distributed in geographic space. Factor 1 described a
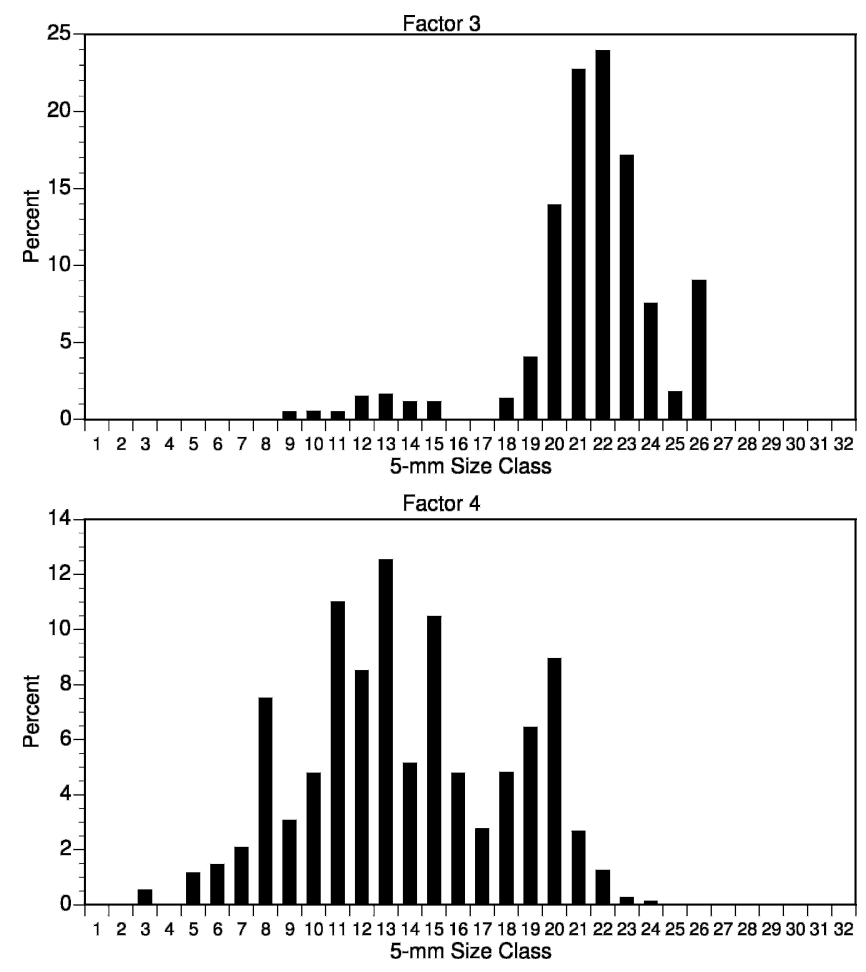

Figure 4. Summary size-frequency distributions for all stations with factor scores $>1.0$ for Factor 3 or Factor 4. Size classes are in 5-mm increments. Thus size class 1 represents clams $>0-5 \mathrm{~mm}$; size class 2 , clams $>5-10 \mathrm{~mm}$, etc.

series of assemblages characterized by a bimodal size-frequency distribution in which one mode included the smallest size classes collected and the other mode contained relatively large individuals. The distribution of stations yielding ocean quahogs in this size-

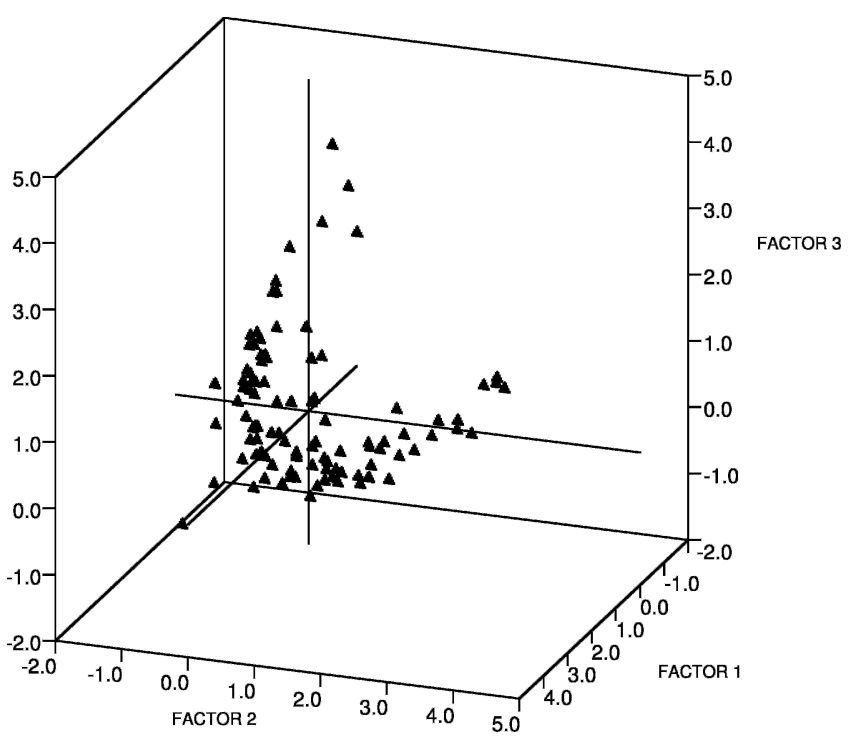

Figure 5. The location of stations in factor space. End-member sizefrequency distributions are shown in Figures 3 and 4. Diffusion of stations off the Factor 2-Factor 3 axis is a function of the importance of the smallest ocean quahog size classes in the size-frequency distribution. Diffusion of stations off the Factor 1-Factor 2 axis is a function of the importance of the largest ocean quahog size classes in the sizefrequency distribution. 


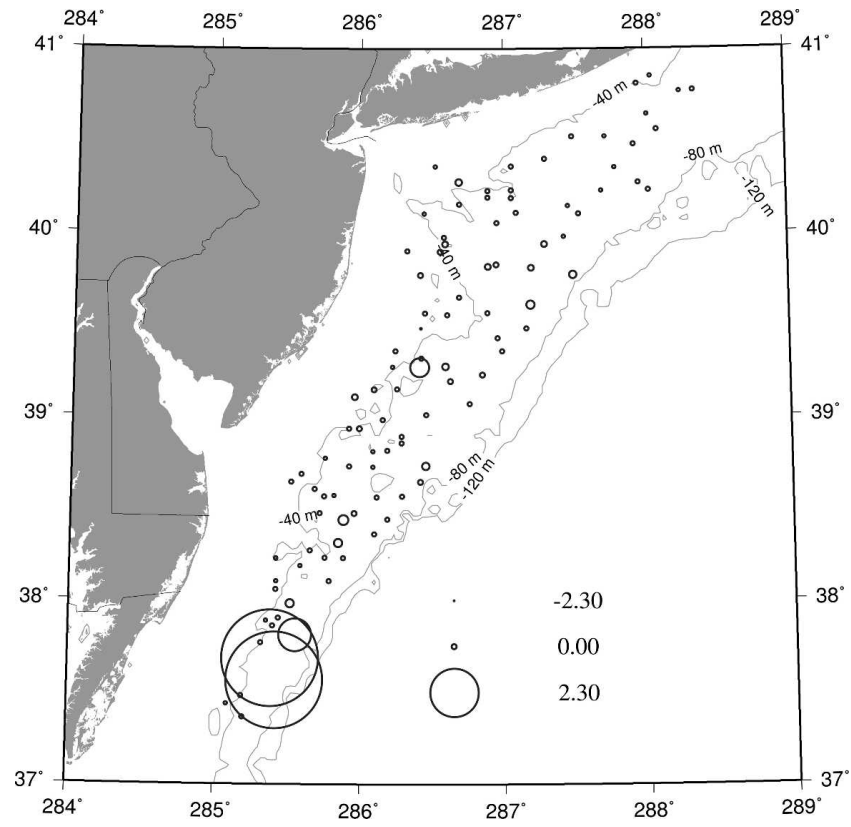

Figure 6. The geographic distribution of stations with high Factor 1 scores (Fig. 3). Factor 1 is weighted most heavily by the smallest ocean quahog size classes. Circle diameter is nonlinearly proportional to factor score. Circle diameter is calculated as $e^{(\text {Factor } 1)} / 10$. Legend shows the size of circles with factor scores of $-2.3,0.0$ and +2.3 . frequency distribution was strongly determined by depth and latitude (Fig. 6, Table 2). Stations deeper than $55 \mathrm{~m}$ yielded significantly more examples of this type of size-frequency distribution than shallower stations. Assemblages scoring high on Factor 1 were predominately distributed south of Atlantic City and mostly south of Delaware Bay (Fig. 6). Stations south of $38^{\circ} \mathrm{N}$ were significantly more likely to be characterized by ocean quahogs with this type of size-frequency distribution (Table 2). Total catch was a significant covariate. This type of size-frequency distribution tended to occur in locations where ocean quahogs were less abundant. Interaction terms between combinations of geographic region, depth zone and total catch were consistently highly significant (Table 2). Thus, considerable variability existed in the distribution of small quahogs within geographic regions, across depths and with respect to total catch.

Assemblages scoring high on Factor 2, and thus containing mostly individuals of intermediate size, $66-95 \mathrm{~mm}$, occurred primarily northeast of Hudson Canyon (Fig. 7). However, no main effect was significant for Factor 2 (Table 2). Perusal of Figure 7 suggests that the apparent absence of a significant effect of geographic region on the distribution of assemblages of this type was caused primarily by the failure of the latitudinal zones, as defined in degree intervals, to adequately describe the spatial distribution of stations with assemblages characterized by this size-frequency distribution. Least-square means analysis revealed that stations between $38^{\circ} \mathrm{N}$ and $39^{\circ} \mathrm{N}$ were significantly less likely to have assemblages with this type of size-frequency distribution than sta-

TABLE 2.

Results of ANCOVA analysis using as the dependent variable the four PCA factors obtained using the complete standardized size-frequency distribution for each tow. Depth zones and geographic regions are defined in the Methods section. Total catch was used as a covariate. not significant at $\alpha=0.05$. *, interaction term.

\begin{tabular}{|c|c|c|c|c|c|c|c|}
\hline & & Factor 1 & & Factor 2 & & Factor 3 & Factor 4 \\
\hline \multicolumn{2}{|c|}{ Depth Zone } & $P<0.0001^{\mathrm{a}}$ & & - & & $P=0.036^{\mathrm{b}}$ & $P=0.029^{\mathrm{c}}$ \\
\hline \multicolumn{2}{|c|}{ Geographic Region } & $P<0.0001^{\mathrm{d}}$ & & - $^{\mathrm{e}}$ & & $-^{f}$ & $P=0.023^{\mathrm{g}}$ \\
\hline \multicolumn{2}{|c|}{ Depth*Region } & $P<0.0001$ & & - & & - & - \\
\hline \multicolumn{2}{|c|}{ Total Catch } & $P<0.0001$ & & - & & - & $P=0.0064$ \\
\hline \multicolumn{2}{|c|}{ Total Catch*Depth } & $P<0.0001$ & & - & & - & $P=0.0078$ \\
\hline \multicolumn{2}{|c|}{ Total Catch*Region } & $P<0.0001$ & & - & & - & $P=0.013$ \\
\hline \multicolumn{2}{|c|}{ Total Catch*Depth*Region } & $P<0.0001$ & & - & & - & $P=0.035$ \\
\hline (a) & $43-55 \mathrm{~m}$ & $<43 \mathrm{~m}$ & (d) & & $39-40^{\circ}$ & $38-39^{\circ}$ & $<38^{\circ}$ \\
\hline $\begin{array}{l}>55 \mathrm{~m} \\
43-55 \mathrm{~m}\end{array}$ & $P<0.0001$ & $\begin{array}{c}P<0.0001 \\
-\end{array}$ & $\begin{array}{l}>40^{\circ} \\
39-40^{\circ} \\
38-39^{\circ}\end{array}$ & & - & - & $\begin{array}{l}P<0.0001 \\
P<0.0001 \\
P<0.0001\end{array}$ \\
\hline (b) & $43-55 \mathrm{~m}$ & $<43 \mathrm{~m}$ & (e) & & $39-40^{\circ}$ & $38-39^{\circ}$ & $<38^{\circ}$ \\
\hline $\begin{array}{l}>55 \mathrm{~m} \\
43-55 \mathrm{~m}\end{array}$ & - & $P<\overline{0.0001}$ & $\begin{array}{c}>40^{\circ} \\
39-40^{\circ} \\
38-39^{\circ}\end{array}$ & & - & $\begin{aligned} P= & 0.0063 \\
& -\end{aligned}$ & $\begin{array}{l}- \\
-\end{array}$ \\
\hline (c) & $43-55 \mathrm{~m}$ & $<43 \mathrm{~m}$ & (f) & & $39-40^{\circ}$ & $38-39^{\circ}$ & $<38^{\circ}$ \\
\hline \multirow[t]{3}{*}{$\begin{array}{l}>55 \mathrm{~m} \\
43-55 \mathrm{~m}\end{array}$} & $P=0.003$ & $\begin{array}{c}P=0.002 \\
-\end{array}$ & $\begin{array}{c}>40^{\circ} \\
39-40^{\circ} \\
38-39^{\circ}\end{array}$ & & $P=0.0004$ & $P=\overline{0} .012$ & $\begin{array}{l}- \\
-\end{array}$ \\
\hline & & & (g) & & $39-40^{\circ}$ & $38-39^{\circ}$ & $<38^{\circ}$ \\
\hline & & & $\begin{array}{c}>40^{\circ} \\
39-40^{\circ} \\
38-39^{\circ}\end{array}$ & & - & - & $\begin{array}{l}P=0.0018 \\
P=0.002 \\
P=0.003\end{array}$ \\
\hline
\end{tabular}




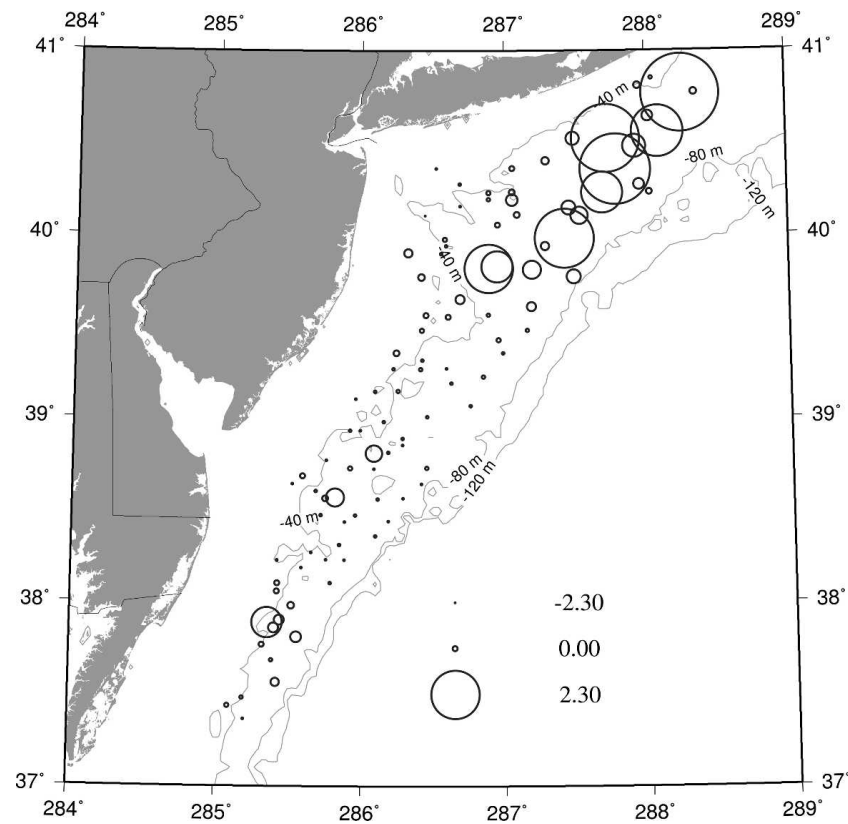

Figure 7. The geographic distribution of stations with high Factor 2 scores (Fig. 3). Factor 2 is weighted most heavily by ocean quahogs of intermediate size: $66-95 \mathrm{~mm}$. Circle diameter is nonlinearly proportional to factor score. Circle diameter is calculated as $e^{(\text {Factor } 2)} / \mathbf{1 0}$. Legend shows the size of circles with factor scores of $\mathbf{- 2 . 3 , 0 . 0}$ and +2.3 .

tions north of $40^{\circ} \mathrm{N}$ (Table 2). Further perusal of Figure 7 shows that this zone of low probability actually extends northward to $\sim 39.5^{\circ} \mathrm{N}$.

Factor 3 described size-frequency distributions composed nearly exclusively of the largest individuals. These assemblages predominated on the inshore half of the cross-shelf distribution of this species (Fig. 8). These assemblages were significantly more common at depths $<43 \mathrm{~m}$ (Table 2). Geographic distribution did not exert a significant effect overall. Lease-square means analyses, however, revealed that assemblages with this type of sizefrequency distribution occurred more commonly between $39^{\circ} \mathrm{N}$ and $40^{\circ} \mathrm{N}$ than north of $40^{\circ} \mathrm{N}$ or between $38^{\circ} \mathrm{N}$ and $39^{\circ} \mathrm{N}$ (Table 2). Thus, stations with populations of this type were most common off the New Jersey coast (Fig. 8).

Neither Factors 2 nor 3 were significantly influenced by total catch. Neither of these factors were characterized by an abundance of ocean quahogs less than $65 \mathrm{~mm}$ in their size-frequency distribution. Factor 4 assemblages, in contrast, were characterized by a large proportion of such small animals. As with Factor 1 assemblages that were also so characterized, Factor 4 assemblages were significantly influenced by total catch (Table 2). Moreover, like Factor 1 assemblages and also unlike Factors 2 and 3 assemblages, interaction terms between depth zone, geographic region and total catch were routinely significant (Table 2 ). Trends with depth and latitude were nearly opposite of trends identified with Factor 1 assemblages. Assemblages with high Factor 4 scores were distributed more uniformly with latitude, although more commonly observed in the south; they also tended to occur in the central to outer portion of the cross-shelf distribution (Fig. 9). Stations characterized by assemblages with Factor 4-type size-frequency distributions were significantly more common at depths shallower than 55 $\mathrm{m}$, particularly common in the 43-55 $\mathrm{m}$ depth zone and occurred significantly more frequently at latitudes north of $38^{\circ} \mathrm{N}$ and south of $40^{\circ} \mathrm{N}$ (Table 2, Fig. 9).

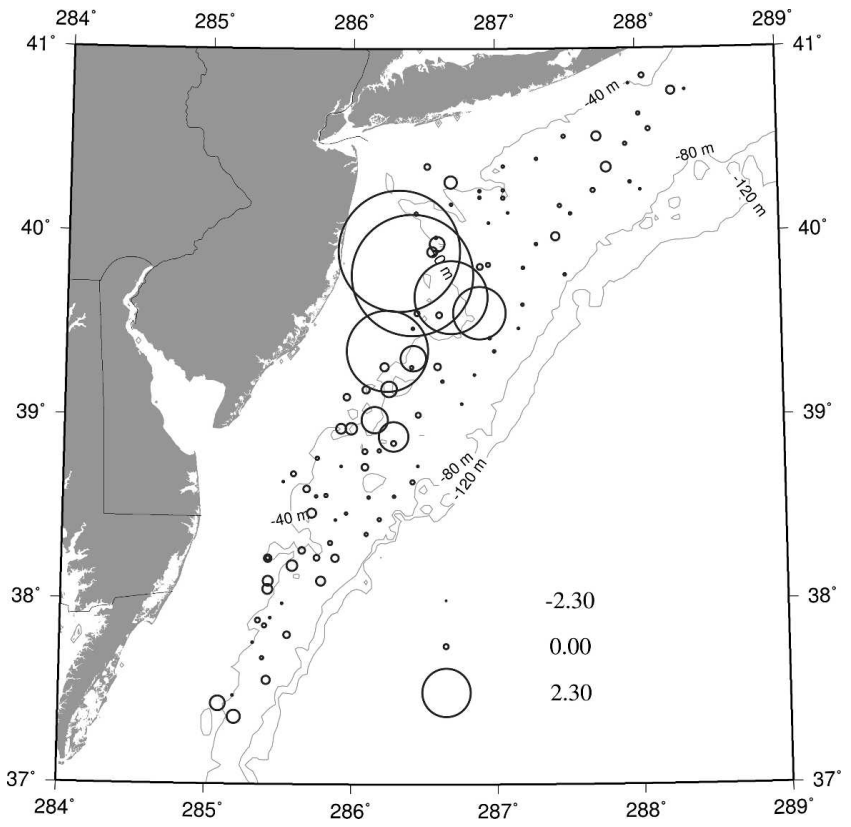

Figure 8. The geographic distribution of stations with high Factor 3 scores (Fig. 4). Factor 3 is weighted most heavily by the largest ocean quahog size classes. Circle diameter is nonlinearly proportional to factor score. Circle diameter is calculated as $e^{(\text {Factor } 3)} / 10$. Legend shows the size of circles with factor scores of $\mathbf{- 2 . 3 , 0 . 0}$ and +2.3 .

\section{End-member Size-frequency Distributions, Smaller Size Classes}

Those clams $<80 \mathrm{~mm}$ in size also were analyzed separately to distinguish different modes and tempos of recruitment. The first four PCA factors explained $54 \%$ of the total variation in the dis-

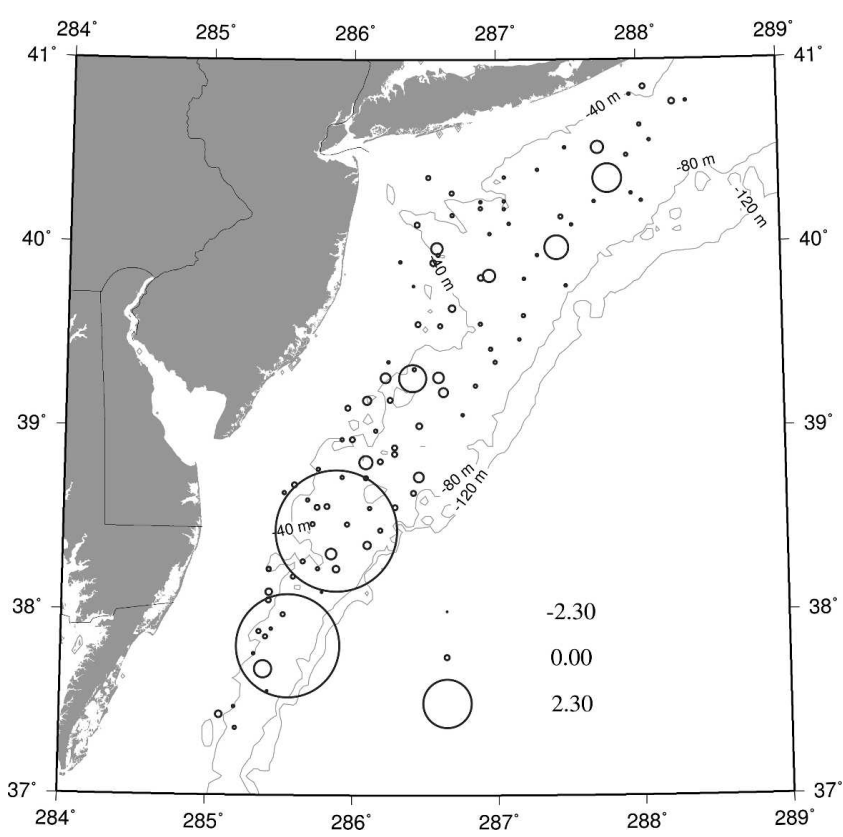

Figure 9. The geographic distribution of stations with high Factor 4 scores (Fig. 4). Factor 4 is weighted most heavily by the larger of the smaller ocean quahog size classes; size classes intermediate between those loading on Factors 1 and 2. Circle diameter is nonlinearly proportional to factor score. Circle diameter is calculated as $e^{(\text {Factor } 4)} / 10$. Legend shows the size of circles with factor scores of $-2.3,0.0$, and +2.3 . 
tribution of these smaller clams among the sampled assemblages; including PCA Factors 5 and 6 raised this value to $70 \%$.

Assemblages scoring high on Factor 1 were characterized by a range of sizes of small clams between 25 and $80 \mathrm{~mm}$ (Fig. 10). However, size classes in the range $16-35 \mathrm{~mm}$ principally defined which assemblages scored highest on Factor 1. Consequently, these assemblages were characterized by temporally consistent recruitment as well as the most recent recruitment events.

The remaining factors describe size-frequency distributions in which a narrower size range of small clams contributed the bulk of the $<80$-mm complement of the assemblage. For example, most small clams in assemblages with high Factor 2 scores were 50-60 $\mathrm{mm}$ in size (Fig. 10). End-member size-frequency distributions described by Factors 5 and 6, like Factor 2, were characterized by strong size-restricted modes (Fig. 11). Those assemblages with high Factor 5 scores contained a disproportionately large number of small ocean quahogs $41-45 \mathrm{~mm}$ in size (Fig. 11). Those assemblages with high Factor 6 scores contained a disproportionately large number of small ocean quahogs $61-65 \mathrm{~mm}$ in size (Fig. 11).

Populations with high Factor 3 and 4 scores were intermediate between the single-mode extreme of Factors 2, 5 and 6 and the continuous recruitment extreme of Factor 1. Factor 3 sizefrequency distributions were relatively enriched in animals 66-70 $\mathrm{mm}$, although most size classes $46-80 \mathrm{~mm}$ were present (Fig. 12). Factor 4 size-frequency distributions were relatively enriched in animals $46-50 \mathrm{~mm}$, although, again, most size classes $46-80 \mathrm{~mm}$ were present (Fig. 12).
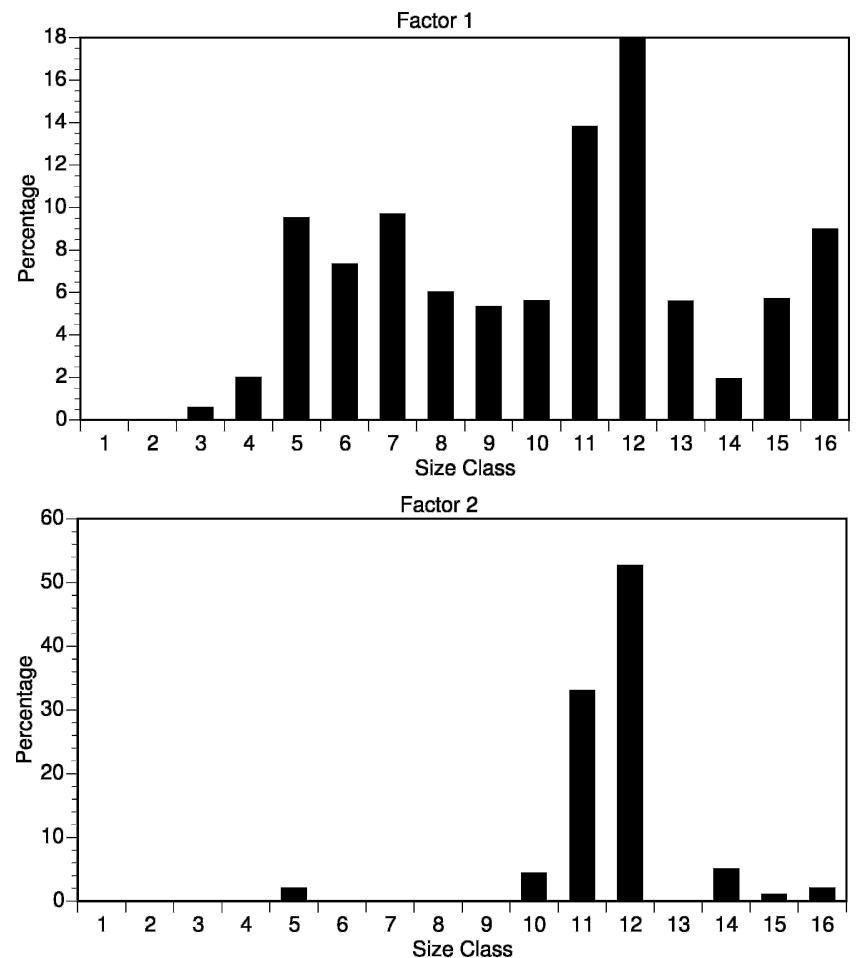

Figure 10. Summary size-frequency distributions for all stations with factor scores above 1.0 for Factors 1 and 2, based on the analysis only of ocean quahogs $<80 \mathbf{~ m m}$ in size. Size classes are in $5-\mathrm{mm}$ increments. Thus size class 1 represents clams $>0-5 \mathrm{~mm}$; size class 2, clams $>5-10$ mm, etc.
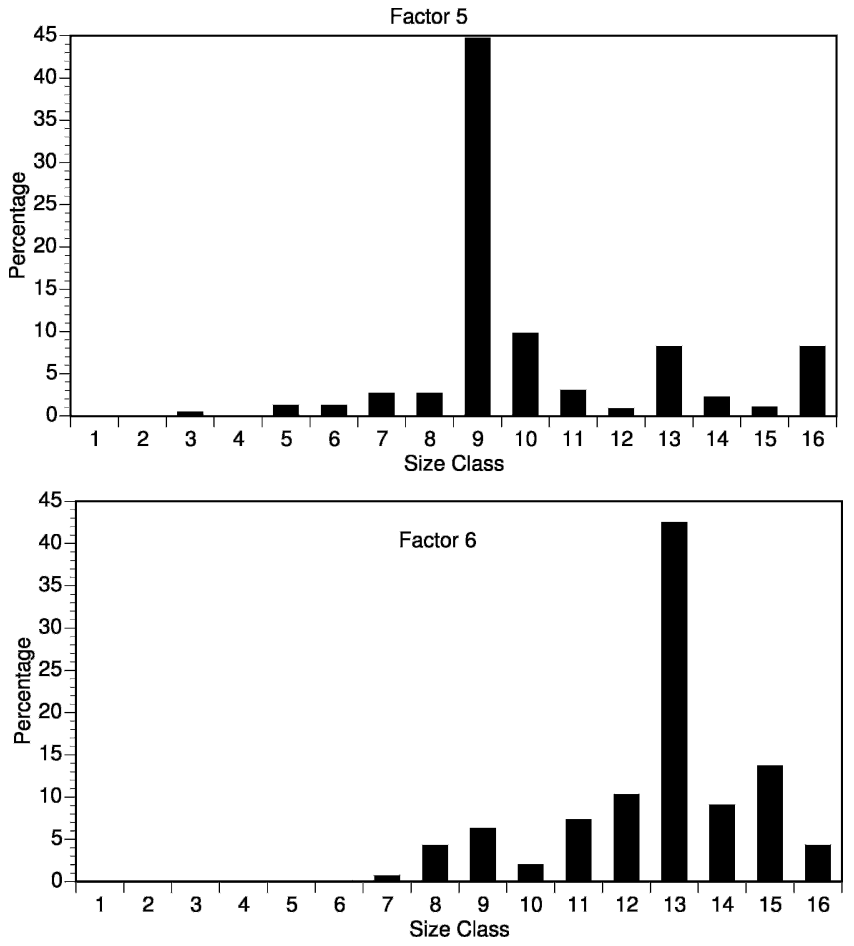

Figure 11. Summary size-frequency distributions for all stations with factor scores above 1.0 for Factors 5 and 6, based on the analysis only of ocean quahogs $<80 \mathrm{~mm}$ in size. Size classes are in 5-mm increments. Thus size class 1 represents clams $>0-5 \mathrm{~mm}$; size class 2, clams $>5-10$ mm, etc.

\section{Statistical Relationships, Smaller Size Classes}

Small ocean quahogs were caught in 93 of 104 stations. All of the remaining 11 stations, with assemblages solely comprising individuals $\geq 80 \mathrm{~mm}$, were distributed along the inner edge of the depth range for ocean quahogs south of Hudson Canyon (Fig. 13).

Factor 1 represents size-frequency distributions characterized by a wide range and a relatively even apportionment of size classes under $80 \mathrm{~mm}$. Assemblages with this size structure are characteristic of areas recruiting relatively continuously. The distribution of stations with populations having this type of size-frequency distribution was significantly influenced by depth and geographic region (Table 3). Assemblages with more or less continuous recruitment were more frequently encountered at depths $>55 \mathrm{~m}$ and near the southern end of the species' range south of $38^{\circ} \mathrm{N}$ (Fig. 13).

Factor 2 represents a series of assemblages in which most small individuals $<80 \mathrm{~mm}$ were $50-60 \mathrm{~mm}$ in size. Assemblages that had this characteristic size structure were significantly more common at depths $<43 \mathrm{~m}$, but just barely so (Table 3 ). Why the relationship with depth is weak is explained by the strong geographic dependency demonstrated in the distributional pattern of these assemblages. Size-frequency distributions of this type were encountered significantly more often between $38^{\circ} \mathrm{N}$ and $40^{\circ} \mathrm{N}$ (Table 3 , Fig. 14). Shallow assemblages falling outside of this latitudinal band had no instances of this type of size-frequency pattern.

Factor 3 represents a set of assemblages in which a range of small size classes were present but in which ocean quahogs 66-70 $\mathrm{mm}$ in size were disproportionately represented. Neither depth nor geographic region significantly influenced the distribution of assemblages with this type of size structure (Table 3 ). Stations of this 

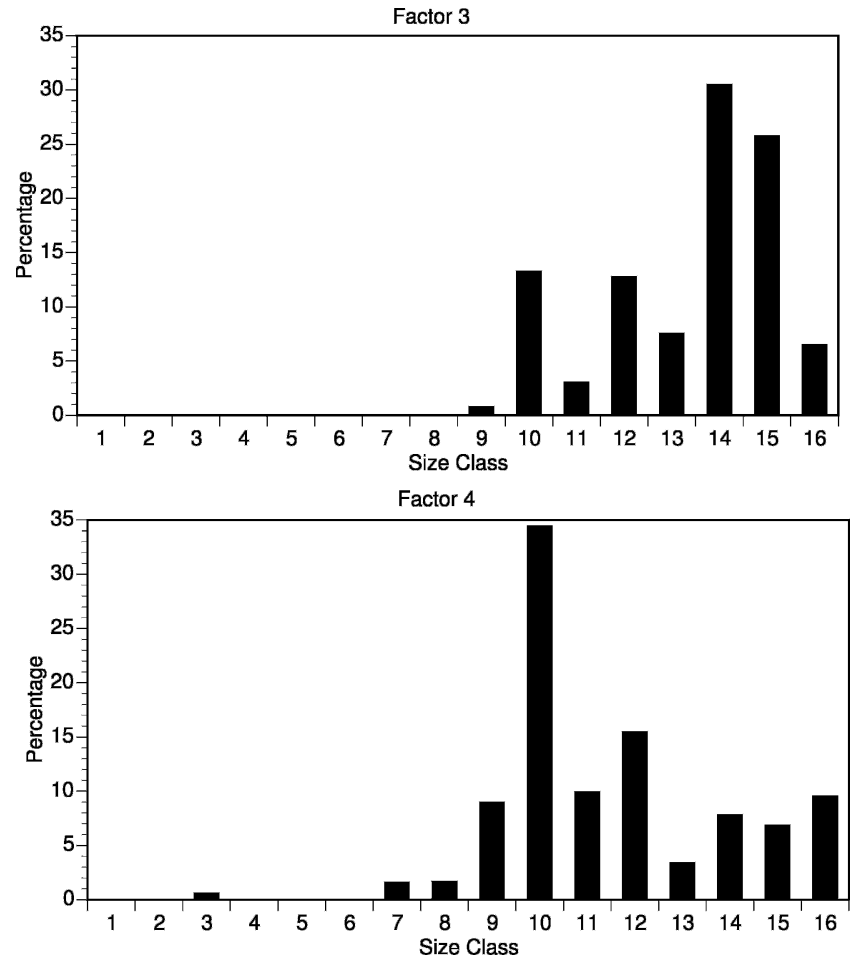

Figure 12. Summary size-frequency distributions for all stations with factor scores above 1.0 for Factors 3 and 4, based on the analysis only of ocean quahogs $<80 \mathrm{~mm}$ in size. Size classes are in 5-mm increments. Thus size class 1 represents clams $>0-\mathbf{~ m m}$; size class 2 , clams $>5-10$ mm, etc.

sort are scattered throughout much of the Mid-Atlantic Bight (Fig. 15). Factor 4 assemblages are similar in size structure to Factor 3 assemblages except that more of the individuals fall in the 46-50 $\mathrm{mm}$ range. Depth did not significantly influence the distributional pattern. The frequency of occurrence was somewhat higher between $38^{\circ} \mathrm{N}$ and $39^{\circ} \mathrm{N}$ than above $40^{\circ} \mathrm{N}$ (Table 3), however these assemblages were distributed throughout much of the geographic range south of $40^{\circ} \mathrm{N}$ (Fig. 16).

Factor 5 described a size-frequency structure with a disproportionately large number of small ocean quahogs $41-45 \mathrm{~mm}$ in size. The distribution of stations with ocean quahog assemblages with size characteristics of this type was not significantly influenced by depth or geographic region (Table 3), although visually, such stations were somewhat rarer north of $40^{\circ} \mathrm{N}$ (Fig. 17). Factor 6 described a size-frequency structure with a disproportionately large number of small ocean quahogs $61-65 \mathrm{~mm}$ in size. Depth was a significant determinant of the distribution of assemblages so characterized (Table 3), however an a posterior test did not localize the reason for the significant main effect. Geographic region did not significantly influence distribution (Table 3). Visually, stations supporting assemblages of this type were distributed throughout the Mid-Atlantic with shallower stations seemingly more likely to be represented (Fig. 18).

\section{DISCUSSION}

\section{Perspective}

Population size frequencies integrate the recent record of recruitment, growth and mortality of the comprising cohorts of in-

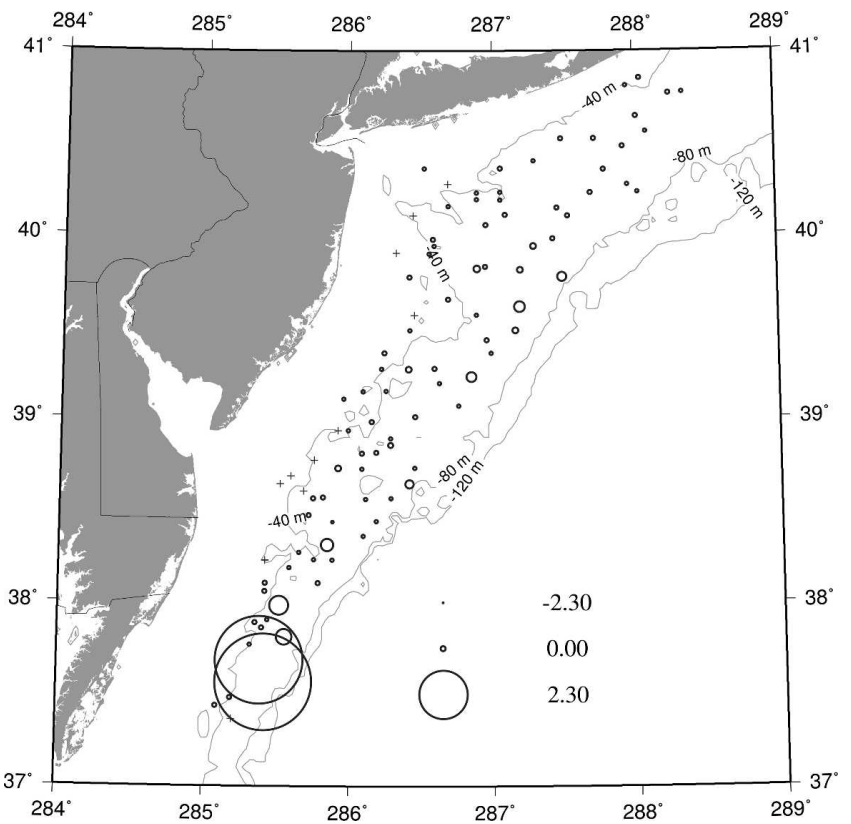

Figure 13. The geographic distribution of stations with high Factor 1 scores (Fig. 10). Factor 1 is weighted most heavily by small ocean quahogs in the size range $16-35 \mathrm{~mm}$, but size-frequencies scoring high on Factor 1 were characterized by having a range of sizes of small clams between 25 and $80 \mathrm{~mm}$. Circle diameter is nonlinearly proportional to factor score. Circle diameter is calculated as $e^{(\text {Factor } 1)} / 10$. Legend shows the size of circles with factor scores of $-\mathbf{2 . 3}, 0.0$ and +2.3 . Crosses indicate stations where no ocean quahogs $<80 \mathrm{~mm}$ were collected.

dividuals (Hallam 1972, Craig \& Oertel 1966). For animals with long life spans, the frequency of recruitment can be a particularly important determining factor. Ocean quahogs, Arctica islandica, are among the longest-lived invertebrates (Forster 1981, Powell \& Cummins 1985, Heller 1990, Callender \& Powell 1997), living upwards of 200 y (Ropes \& Jearld 1987, Fritz 1991). The species is boreal amphi-Atlantic (Dahlgren et al. 2000). From this perspective, the intrusion of a substantial stock of ocean quahogs southward along the Mid-Atlantic coast of the United States is remarkable (Dahlgren et al. 2000). One might anticipate that this population would recruit less predictably and that, in fact, portions of it might not be self-sustaining but depend on more northerly spawn. Such is often the character of populations at the edge of a species' range. Although northeast-coast populations containing small quahogs have been reported (Murawski \& Serchuk 1979, Rowell et al. 1990, Ropes et al. 1984, Brey et al. 1990), and reproduction and larval transport in the Mid-Atlantic have been studied (Jones 1981, Mann 1982, Mann 1986), the notion that these populations recruit rarely has achieved some renown (Fogarty 1981, Kennish \& Lutz 1995, Fritz 1991, NEFSC 1995). Lewis et al. (2001) documented an increase in recruitment on Georges Bank since the 1980s but noted as well the apparently low number of recruits in the area of the Mid-Atlantic Bight and the aperiodicity of recruitment throughout much of the western Atlantic. This contrasts to an apparently more predictable recruitment in Icelandic populations (Thórarinsdóttir \& Jóhannesson 1996).

The apparent rarity of recruitment west and south of Georges Bank, however, has profound implications for the ocean quahog 
TABLE 3.

Results of ANCOVA analysis using as the dependent variable the six PCA factors obtained using the standardized size-frequency distributions for each tow with the size classes restricted to animals $<80 \mathrm{~mm}$. Depth zones and geographic regions are defined in the Methods section. The covariate, total catch, was the total of all ocean quahog size classes, not just those $<80$ mm. - , not significant at $\alpha=0.05$. *, interaction term.

\begin{tabular}{|c|c|c|c|c|c|c|c|}
\hline & & Factor 1 & Factor 2 & Factor 3 & Factor 4 & Factor 5 & Factor 6 \\
\hline \multicolumn{2}{|c|}{ Depth Zone } & $P<0.0001^{\mathrm{a}}$ & $-^{\mathrm{b}}$ & - & - & - & $P=0.036$ \\
\hline \multicolumn{2}{|c|}{ Geographic Region } & $P<0.0001^{\mathrm{c}}$ & $P<0.0001^{\mathrm{d}}$ & - & - $^{\mathrm{e}}$ & - & - \\
\hline \multicolumn{2}{|c|}{ Depth*Region } & $P<0.0001$ & - & - & - & - & - \\
\hline \multicolumn{2}{|c|}{ Total Catch } & $P<0.0001$ & - & - & - & - & - \\
\hline \multicolumn{2}{|c|}{ Total Catch*Depth } & $P<0.0001$ & - & - & - & - & - \\
\hline \multicolumn{2}{|c|}{ Total Catch*Region } & $P<0.0001$ & $P=0.0035$ & - & - & - & - \\
\hline \multicolumn{2}{|c|}{ Total Catch*Depth*Region } & $P<0.0001$ & $P=0.022$ & - & - & - & - \\
\hline (a) & $43-55 \mathrm{~m}$ & $<43 \mathrm{~m}$ & (c) & \multicolumn{2}{|r|}{$39-40^{\circ}$} & $38-39^{\circ}$ & $<38^{\circ}$ \\
\hline $\begin{array}{l}>55 \mathrm{~m} \\
43-55 \mathrm{~m}\end{array}$ & $P<0.0001$ & $\begin{array}{c}P<0.0001 \\
-\end{array}$ & $\begin{array}{l}>40^{\circ} \\
39-40^{\circ} \\
38-39^{\circ}\end{array}$ & \multicolumn{2}{|r|}{-} & - & $\begin{array}{l}P<0.0001 \\
P<0.0001 \\
P<0.0001\end{array}$ \\
\hline (b) & $43-55 \mathrm{~m}$ & $<43 \mathrm{~m}$ & (d) & \multicolumn{2}{|r|}{$39-40^{\circ}$} & $38-39^{\circ}$ & $<38^{\circ}$ \\
\hline \multirow[t]{3}{*}{$\begin{array}{l}>55 \mathrm{~m} \\
43-55 \mathrm{~m}\end{array}$} & - & $P=\overline{0.048}$ & $\begin{array}{c}>40^{\circ} \\
39-40^{\circ} \\
38-39^{\circ}\end{array}$ & \multicolumn{2}{|r|}{$P=0.0001$} & $P=\overline{0} .025$ & - \\
\hline & & & (e) & \multicolumn{2}{|r|}{$39-40^{\circ}$} & $38-39^{\circ}$ & $<38^{\circ}$ \\
\hline & & & $\begin{array}{c}>40^{\circ} \\
39-40^{\circ} \\
38-39^{\circ}\end{array}$ & & - & - & - \\
\hline
\end{tabular}

fishery that began in earnest in the early 1980s and now has a yearly quota of 4.5 million bushels (NEFSC 2000). The presence of the fishery, in turn, has profound implications for ocean quahog population dynamics. In early stock assessments, a so-called min-

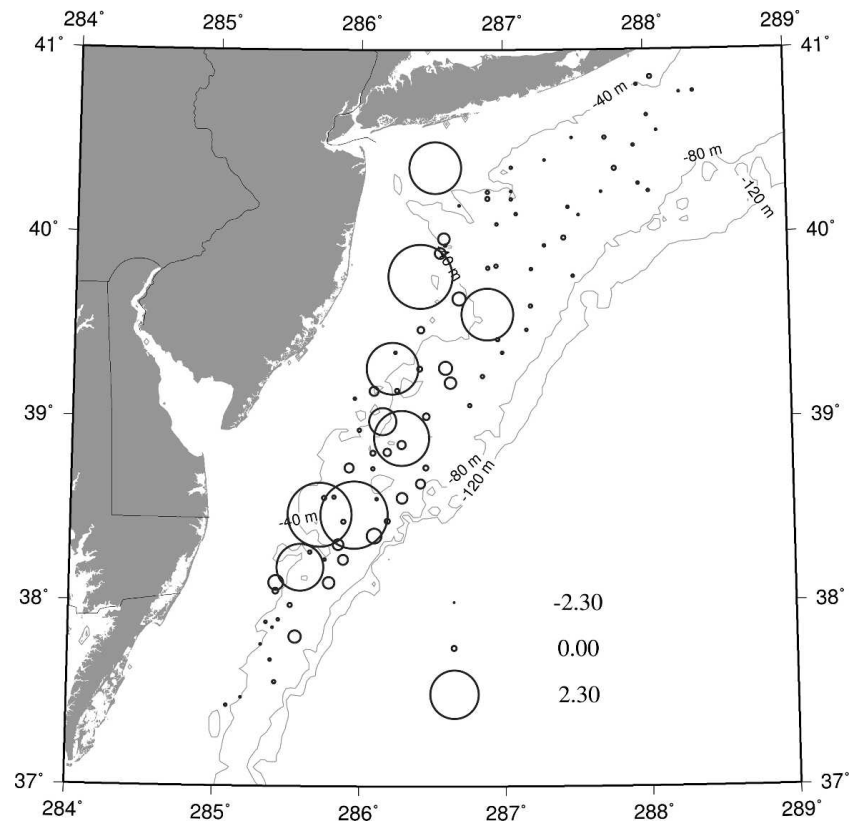

Figure 14. The geographic distribution of stations with high Factor 2 scores (Fig. 10). Most small clams in populations with high Factor 2 scores were $\mathbf{5 0 - 6 0 ~} \mathrm{mm}$ in size. Circle diameter is nonlinearly proportional to factor score. Circle diameter is calculated as $e^{(\text {Factor } 2)} / \mathbf{1 0}$. Legend shows the size of circles with factor scores of $\mathbf{- 2 . 3 , 0 . 0}$ and +2.3 . ing model was used (NEFSC 1995). This model assumed that recruitment was sufficiently rare that population dynamics could be approximated by the process of the lowering of abundance by fishing. This view, in fact, has solid theoretical roots in the con-

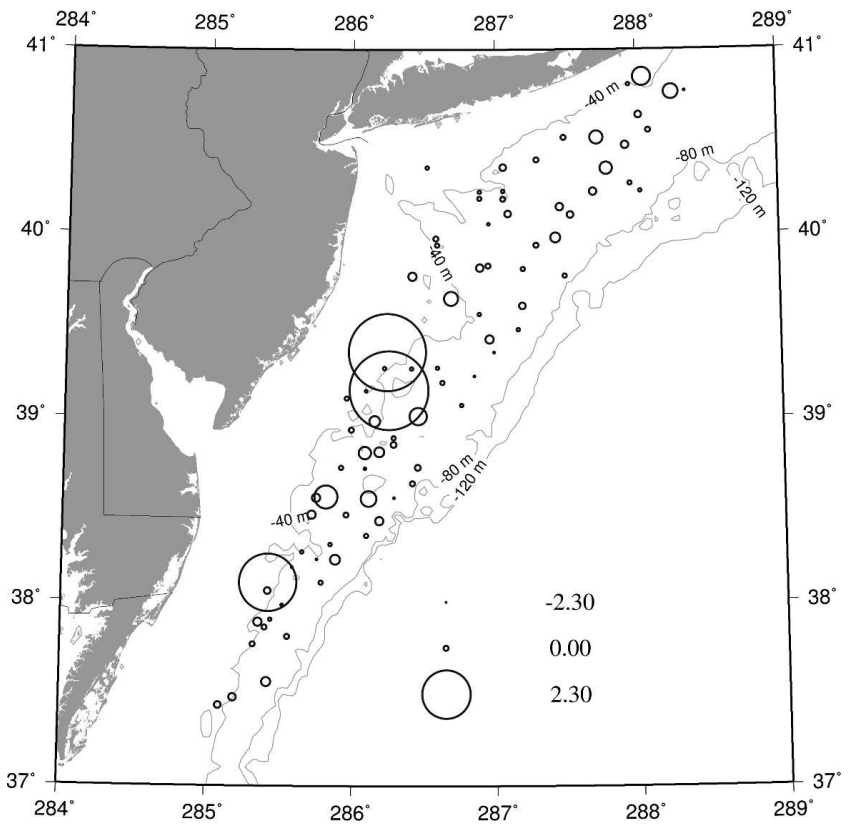

Figure 15. The geographic distribution of stations with high Factor 3 scores (Fig. 12). Factor 3 size-frequencies were relatively enriched in animals $66-70 \mathrm{~mm}$. Circle diameter is nonlinearly proportional to factor score. Circle diameter is calculated as $e^{(\text {Factor } 3)} / 10$. Legend shows the size of circles with factor scores of $-2.3,0.0$ and +2.3 . 


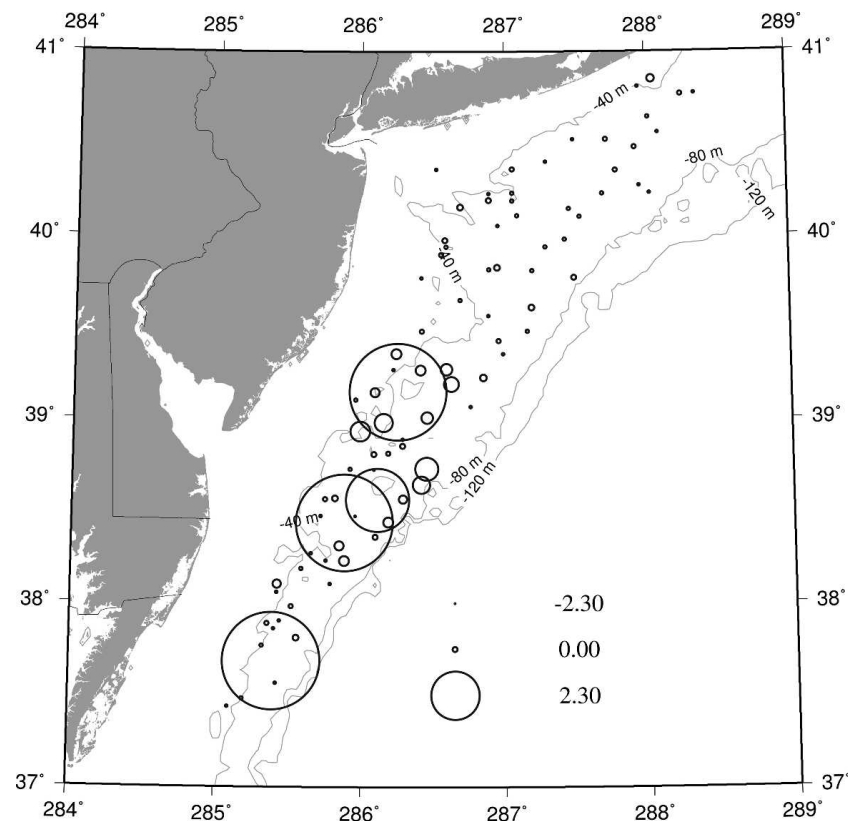

Figure 16. The geographic distribution of stations with high Factor 4 scores (Fig. 12). Factor 4 size-frequencies were relatively enriched in animal $\mathbf{4 6}-\mathbf{5 0} \mathbf{~ m m}$. Circle diameter is nonlinearly proportional to factor score. Circle diameter is calculated as $e^{(\text {Factor } 4)} / 10$. Legend shows the size of circles with factor scores of $-2.3,0.0$ and +2.3 .

cepts of carrying capacity and maximum sustainable yield. One assumes that the ocean quahog population was at or near carrying capacity prior to the fishery beginning circa 1980 (NEFSC 2000). One characteristic of such populations is that recruitment balances

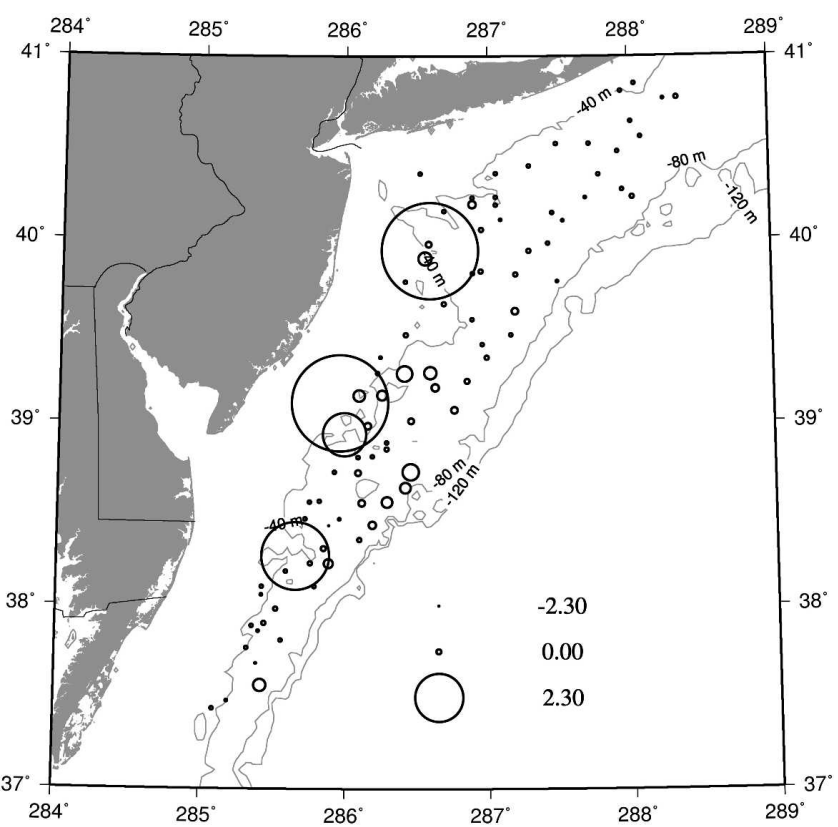

Figure 17. The geographic distribution of stations with high Factor 5 scores (Fig. 11). Those stations with high Factor 5 scores contained a disproportionately large number of small ocean quahogs $41-45 \mathrm{~mm}$ in size. Circle diameter is nonlinearly proportional to factor score. Circle diameter is calculated as $e^{(\text {Factor } 5)} / 10$. Legend shows the size of circles with factor scores of $\mathbf{- 2 . 3 , 0 . 0}$ and +2.3 .

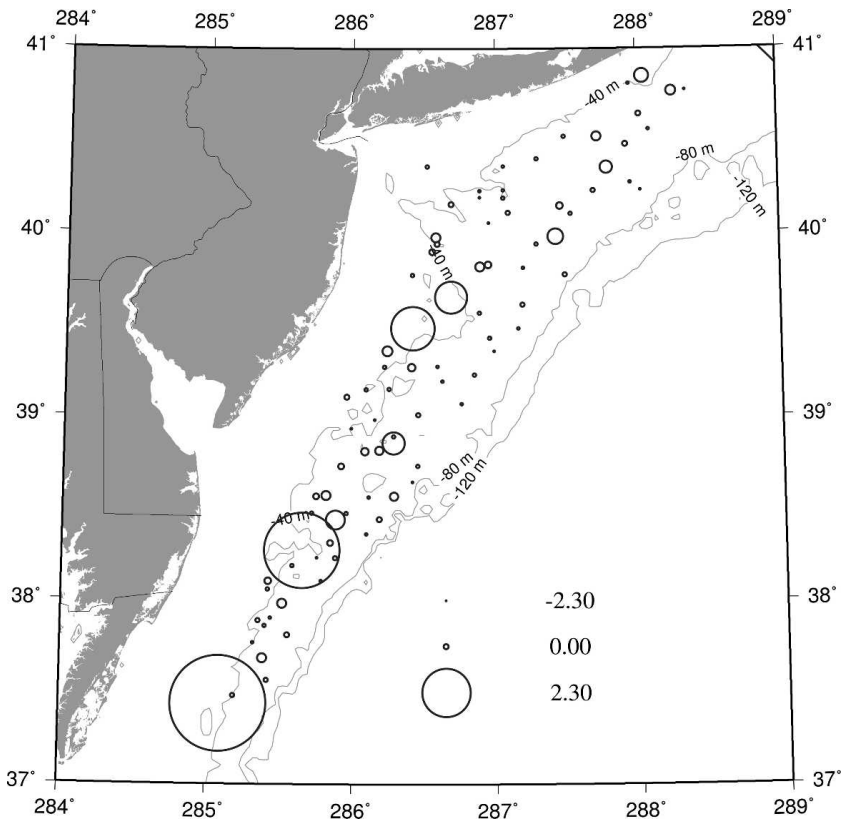

Figure 18. The geographic distribution of stations with high Factor 6 scores (Fig. 11). Those stations with high Factor 6 scores contained a disproportionately large number of small ocean quahog $61-65 \mathrm{~mm}$ in size. Circle diameter is nonlinearly proportional to factor score. Circle diameter is calculated as $e^{(\text {Factor })} / 10$. Legend shows the size of circles with factor scores of $\mathbf{- 2 . 3 , 0 . 0}$ and +2.3 .

mortality (Hilborn \& Walters 1992). For a long-lived species with a low mortality rate, such as Arctica islandica, the necessary corollary is that the rate of recruitment must be extremely low at carrying capacity. Thus, a fishery at its inception, even if operating sustainably, would appear to be mining. A sequitur is that recruitment should rise as population biomass declines to the level anticipated at maximum sustainable yield.

The first problem confronting the search for ocean quahog recruitment is delimiting the size classes to which the term "recruit" will apply. The fishery, for the most part, targets ocean quahogs $\geq 80 \mathrm{~mm}$ in length. Animals exceeding $70 \mathrm{~mm}$ in length may already exceed 40 y in age (Murawski et al. 1982, Fritz 1991). The survey gear used by the NMFS probably catches ocean quahogs in the range of $75 \mathrm{~mm}$ or larger quantitatively and with equivalent catchability, although a precise measure of size bias does not exist. Thus, from the perspective of the fishery, and the NMFS survey, the term recruit might apply to quahogs $<70-80$ $\mathrm{mm}$ in length. In this study, we choose $80 \mathrm{~mm}$ as a convenient demarcation.

\section{Ocean Quahog Size-frequency Composition}

The recruitment survey covered the majority of ocean quahog habitat from the southern end of the species' range off Virginia to the continental shelf off the eastern end of Long Island. Sampling covered the entire depth range of this species over this geographic region with the exception of the most inshore reaches off Long Island. Lewis et al. (2001) independently reported information for ocean quahogs on Georges Bank. The necessity of conducting extremely short tows, the concomitant and inescapable uncertainty as to the distance traveled over the bottom by the dredge and the likely nonlinearity in catchability as the dredge fills hamper quantitative analysis. The alternative, a reliance on analysis by propor- 
tion, prevents definitive judgments as to the sustainability of the stock; however, the routine presence of recruits, frequently in relatively high proportions, in tows taken throughout much of the surveyed area bespeaks a more dynamic population structure than might previously have been supposed.

More ocean quahogs were encountered, on a per tow basis, north of about $39.5^{\circ} \mathrm{N}$ latitude (Fig. 2). This latitudinal gradation in ocean quahog abundance is, in part, because of the fishery that has directed more effort for ocean quahogs off the Delmarva Peninsula and New Jersey than elsewhere. This latitudinal gradation in ocean quahog abundance is also due, by inference from the larger number of ocean quahogs $<80 \mathrm{~mm}$, to a higher rate of recruitment north of about $39.5^{\circ} \mathrm{N}$. The simple inference that lower recruitment is expected at the southern extreme of a species' range is, perhaps, not a complete explanation for the observed latitudinal trends. The data induce a less simplistic view. The proportion of recruits in the size-frequency distribution is higher in the south. Thus, abundance is not low in proportion to the density of local broodstock, remembering the caveat that present-day abundance may not equate to abundance at time of settlement. Moreover, the most recent recruitment events seem to be concentrated in the south. Regional and depth-dependent interactions are also much more common in the south (Tables 2,3). Thus, recruitment seems to be a more dynamic and patchy process in the south. Aggregating these observations elicits caution in deducing too much from the larger catches of ocean quahogs $<80 \mathrm{~mm}$ in size north of $39.5^{\circ} \mathrm{N}$.

As interesting is the distribution of stations where no recruits were collected. These stations are nearly exclusively on the inshore edge of the depth distribution of ocean quahogs and south of Hudson Canyon (Fig. 16). Although a temptation exists to explain such a distributional pattern by recent warming trends in the north Atlantic region (e.g., Menzel \& Fabian 1999, Cook et al. 1998, Weinberg et al. 2002, Kim \& Powell 2004), the age of animals $60-80 \mathrm{~mm}$, sizes also absent from these stations, suggests that this trend is of much longer standing than the warming trend that began circa 1990 (Cook et al. 1998).

Although size-frequency distributions often vary complexly among populations of the same species, the 104 assemblages sampled in this study evinced remarkably few structural differences. Most sampled size-frequency distributions could be defined in terms of three end-member size frequencies (Figs. 3, 4, 5). Two of these three contained recruits. One of these latter two contained relatively young recruits $(\leq 65 \mathrm{~mm})$ and larger animals $90-105$ $\mathrm{mm}$ and was, therefore, bimodal. The other contained larger recruits $(66-80 \mathrm{~mm})$ and a smaller subset of the larger animals $(80-95 \mathrm{~mm})$ and was, therefore unimodal. The third contained extremely large $(>100 \mathrm{~mm})$ and old animals nearly exclusively. Each individual size-frequency distribution was an admixture, in varying proportion, of these large old individuals, the older recruits $(66-80 \mathrm{~mm})$, and the younger recruits $(\leq 65 \mathrm{~mm})$. All fell on a mixing diagram defined by these three end members (Fig. 5). No obvious outlier assemblages existed. In fact, the fourth sizefrequency distribution identified by PCA analysis was simply a variant of the first.

End-member size-frequency distributions were not just statistical constructs. These size-frequency distributions were not randomly distributed in geographic space. Their distribution in geographic space delineated regions of active recruitment over the last perhaps score of years, areas that have not seen significant recruitment over perhaps century time scales, and areas that received heavy recruitment for a period of time perhaps two score years ago, accepting an approximate 30-y age estimate for a 70-mm ocean quahog (Murawski et al. 1982). The middle continental shelf off New Jersey, along the inner edge of the depth distribution for ocean quahogs, was disproportionately characterized by assemblages containing mostly the largest individuals. Many of these locations have seen little recruitment over the last century (Fig. 8), once again using age estimates from Murawski et al. (1982). In contrast, north and east of Hudson Canyon is an extensive area in which substantial recruitment occurred perhaps some two score or more years ago (Fig. 7) but little since. Finally, the area south of $39^{\circ} \mathrm{N}$ exemplifies a region where relatively recent recruitment events have occurred.

Overall, the survey suggests three regionally distinctive processes determining the size-frequency distributions of ocean quahog assemblages and recruitment therein. The area northeast of Hudson Canyon is clearly unique in the regionally extensive uniformity of size-frequency distributions among sampled assemblages, the near absence of recruitment over the last score or so of years and the presence of large numbers of the largest recruits $65-80 \mathrm{~mm}$ in size. The inshore (by ocean quahog standards) area off New Jersey is unique in the dominant presence of the largest size classes of ocean quahogs and the remarkable absence of evidence of significant recruitment over an extraordinary time span. The area south of $39^{\circ} \mathrm{N}$ is unique in the wide-spread presence of relatively young recruits, some animals with ages in the time span of the present fishery.

\section{Ocean Quahog Recruitment Dynamics}

Move the focus now explicitly to the size classes $<80 \mathrm{~mm}$ that represent animals that probably recruited sometime in the last twoscore years! Analysis revealed six end-member size-frequency distributions. One of these is characteristic of the larger recruits northeast of Hudson Canyon (Factor 3, Fig. 12), although also found elsewhere (Fig. 15). The other five are restricted to the region south of Hudson Canyon. Of these five, only one comprised a broad relatively evenly apportioned series of size classes (Factor 1, Fig. 10, 13). The remaining four contain single dominant size classes representative of dominant year classes: $40-45 \mathrm{~mm}, 45-50$, 50-60 $\mathrm{mm}$ and 60-65 $\mathrm{mm}$.

The distribution of these assemblage types is determined only in the broadest sense by latitudinal range or depth zone, within the confines of this survey (Table 3). Only the first is significantly influenced by total quahog abundance. Interestingly, this one is also the size-frequency distribution comprising multiple size classes rather evenly apportioned. Assemblages with this sizefrequency structure tend to be located in the south and offshore, at least somewhat coincident with the region believed to have been impacted most by the ocean quahog fishery during the 1980s. The coincidence of heaviest fishery impact, as defined by largest historical change in CPUE (NEFSC 1998), and most consistent recruitment pattern is, perhaps, noteworthy.

The remaining size-frequency styles tend to be quasi-randomly distributed within the general region defined by the species' southern range limit and Hudson Canyon, excluding, of course, much of the area inshore off New Jersey where recruitment is rare. The broad geographic overlap of these size-frequency styles suggests that local conditions determine recruitment success within an area where recruitment has potential much more frequently than it has success. Statistical evaluation reveals that assemblages recruiting often are associated most frequently with significant interaction 
terms with depth zone and geographic region and also most often influenced by local ocean quahog abundance. This reinforces the conclusion that recruitment is complex over small spatial scales.

\section{CONCLUSION}

This survey, combined with recent work by Lewis et al. (2001), demonstrates clearly that ocean quahog recruitment occurs throughout much of the United States east coast range of the species. These recruitment events, however, with one exception, seem to be rare and aperiodic. Recruitment has been more or less continuous of recent only in the southern portion of the ocean quahog's range. However, these recruitment events are not rare in comparison with the animal's life span, only in comparison with the surveys of man. When recruitment events occur, they can be numerically profound. These events also, with three exceptions, seem to be a product of local, rather than regional or depthdependent processes. That is, any local area has potential for recruitment every year, but the degree to which that potential is realized is determined by local processes and these local processes normally militate against the event.

Three exceptions are noteworthy. First is the inshore edge of the species' depth range south of Hudson Canyon that includes a disproportionate number of stations with no evidence of recruitment. Second is the region northeast of Hudson Canyon that clearly expanded rapidly in population abundance some two-score or more years ago but has accreted little since. The recruitment dynamics in this region are unique to the surveyed area of the Mid-Atlantic Bight. Third is the more consistent recruitment pattern observed most often in southern assemblages coincident with the region most heavily impacted by fishing during the first two decades of the ocean quahog fishery. This coincidence is causal under the Schaefer theory of population dynamics (Hilborn \& Walters 1992), if these recruits are young enough.

We have not attempted to answer the question of sustainability of the ocean quahog stock at present fishing levels. Fisheries that target long-lived animals are frequently difficult to manage sustainably. What is clear is that the time scale of such an evaluation for ocean quahogs will strain the capabilities of present fisheries models. An unquestionable conclusion from this study is that recruitment events, although rare in the sense of occurring only once in a score or two of years, are frequent in the context of the +200 -year life span of this species, yet also rare in the context of stock survey timing and fishery dynamics. Moreover, this study strongly suggests that the application of the Schaefer theory of population dynamics of fished populations (Hilborn \& Walters 1992) to the management of the ocean quahog fishery, with its defined relationships between carrying capacity and maximum sustainable yield $\left(B_{m s y}=K / 2\right)$ and its assumption that long-lived species must recruit successfully only rarely when at carrying capacity (Hilborn \& Walters 1992), is meritorious. But, this study also suggests that the history of recruitment over the last perhaps two-score years, revealed by this survey, may be a poor measure of the recruitment dynamics to be anticipated over the next two-score years when the population abundance is reduced to what is anticipated to approximate the biomass at maximum sustainable yield and recruitment rate is expected consequently to continue to rise.

We know only in a general way how old these quahog recruits are. Lewis et al. (2001) have shown recently that ocean quahog growth rates may vary considerably over their United States range. As a consequence, we cannot estimate what fraction of the recruits settled subsequent to the initiation of the fishery circa-1980 using published age-length relationships (e.g., Murawski et al. 1982). The coincidence of the highest numbers of new recruits in the area most heavily fished at the beginning of the fishery is enticing because it meets a basic expectation of fisheries population dynamics, but it cannot yet be judged unquestionably causal. What is more clear is that the recruits observed in this study represent the animals that must balance fishing mortality when the fishery reduces ocean quahog biomass to $B_{m s y}$, an event expected to occur in $\sim 20 \mathrm{y}$. In shorter-lived species, this balance is obtained by the equilibrium of recruitment at $B_{m s y}$ with fishing at $B_{m s y}$. In ocean quahogs, over a much longer period of time, that same equilibrium also can be anticipated. However, a period of time will exist when the stock is at $B_{m s y}$, but recruitment into the fishery is not characteristic of that expected at $B_{m s y}$. That period of time represents a most unusual challenge for fisheries management. Obtaining more information on the abundance of ocean quahogs $<80-\mathrm{mm}$ in size over the coming decade will be critical in establishing the necessary management structure to carry the fishery though this period of disequilibrium.

\section{ACKNOWLEDGMENTS}

The authors appreciate the efficiency and competency of the Captain and crew of the $F / V$ Christie, who carried out this arduous sampling task in 6 days at sea. The authors also wish to thank Oliver Donovan, Bruce Muller, and Peter Smith who helped with sample collection, Bruce Muller who helped in data analysis, and Captain Robert Jarnol of the $F / V$ Christie who designed the gear and deck modifications to permit lining the dredge with small mesh wire and the bypassing of the shaker. The authors appreciate the continuing support of the clam stock assessment team at NMFS-Northeast Fisheries Science Center, including Jim Weinberg and Larry Jacobson, who provided detailed stations locations and additional logistical help in cruise planning. This research was funded by the New Jersey Fisheries Information and Development Center. The authors appreciate this support.

\section{LITERATURE CITED}

Anonymous. 1996. Magnuson-Stevens Fishery Conservation and Management Act. US Dept. Commerce, NOAA, NMFS, NOAA Tech. Mem. NMFS-F SPO-23. $121 \mathrm{pp}$.

Brey, T., W. E. Arntz, D. Pauly \& H. Rumohr. 1990. Arctica (Cyprina) islandica in Kiel Bay (Western Baltic): growth, production and ecological significance. J. Exp. Mar. Biol. Ecol. 136:217-235.

Callender, W. R. \& E. N. Powell. 1997. Autochthonous death assemblages from chemoautotrophic communities at petroleum seeps: paleoproduction, energy flow, and implications for the fossil record. Hist. Biol. 12:165-198.
Cargnelli, L. M., S. J. Griesbach, D. B. Packer \& E. Weissberger. 1999. Ocean quahog, Arctica islandica, life history and habitat characteristics. NOAA Tech. Mem. NMFS NE-148. 12 pp.

Cook, T., M. Folli, J. Klinck, S. Ford \& J. Miller. 1998. The relationship between increasing sea-surface temperature and the northward spread of Perkinsus marinus (Dermo) disease epizootics in oysters. Estuarine Coast. Shelf Sci. 46:587-597.

Craig, G. \& G. Oertel. 1966. Deterministic models of living and fossil populations of animals. Geol. Soc. Lond. 122:315-355.

Dahlgren, T. G., J. R. Weinberg \& K. M. Halanych. 2000. Phylogeography 
of the ocean quahog (Arctica islandica): Influences of paleoclimate on genetic diversity and species range. Mar. Biol. (Berl.) 137:487-495.

Fogarty, M. J. 1981. Distribution and relative abundance of the ocean quahog Arctica islandica in Rhode Island Sound and off Martha's Vineyard, Massachusetts. J. Shellfish Res. 1:33-39.

Forster, G. R. 1981. A note on the growth of Arctica islandica. J. Mar. Biol. Assoc. UK. 61:817.

Fritz, L. W. 1991. Seasonal condition change, morphometrics, growth and sex ratio of the ocean quahog, Arctica islandica (Linnaeus, 1767) off New Jersey, USA. J. Shellfish Res. 10:79-88.

Hallam, A. 1972. Models involving population dynamics. In: T. J. M. Schopf, editor. Models in paleobiology. San Francisco, CA: Freeman, Cooper, and Company. pp. 62-80.

Heller, J. 1990. Longevity in Mollusca. Malacologia 31:259-295.

Hilborn, R. \& C. J. Walters. 1992. Fisheries stock assessment: choice, dynamics \& uncertainty. New York: Chapman \& Hall. 570 pp.

Jones, D. S. 1981. Reproductive cycles of the Atlantic surf clam Spisula solidissima, and the ocean quahog, Arctica islandica off New Jersey. $J$. Shellfish Res. 1:23-32.

Kennish, M. J. \& R. A. Lutz. 1995. Assessment of the ocean quahog, Arctica islandica (Linnaeus, 1767), in the New Jersey fishery. J. Shellfish Res. 14:45-52.

Kennish, M. J., R. A. Lutz, J. A. Dobarro \& L. W. Fritz. 1994. In situ growth rates of the ocean quahog, Arctica islandica (Linnaeus, 1767), in the Middle Atlantic Bight. J. Shellfish Res. 13:473-478.

Kim, Y. \& E. N. Powell. 2004. Surf clam histopathology survey along the Delmarva mortality line. J. Shellfish Res. 23:429-441.

Lewis, C. V. W., J. R. Weinberg \& C. S. Davis. 2001. Population structure and recruitment of the bivalve Arctica islandica (Linnaeus, 1767) on Georges Bank from 1980-1999. J. Shellfish Res. 20:1135-1144.

Mann, R. 1982. The seasonal cycle of gonadal development in Arctica islandica from the southern New England shelf. Fish. Bull. 80:315326.

Mann, R. 1986. Arctica islandica (Linné) larvae: active depth regulators or passive particles. Am. Malacol. Bull. Spec. Ed. 3:51-57.

May, R. M., J. R. Beddington \& J. G. Shepherd. 1978. Exploiting natural populations in an uncertain world. Math. Biosci. 42:219-252.

Menzel, A. \& P. Fabian. 1999. Growing season extended in Europe. Nature 397:659.

Murawski, S. A., J. W. Ropes \& F. M. Serchuk. 1982. Growth of the ocean quahog, Arctica islandica, in the Middle Atlantic Bight. Fish. Bull. 80:21-34.

Murawski, S. A. \& F. M. Serchuk. 1979. Shell length—meat weight relationships of ocean quahogs, Arctica islandica, from the Middle Atlantic shelf. Proc. Natl. Shellfish. Assoc. 69:40-46.

NEFSC. 1995. 19th northeast regional stock assessment workshop (19th SAW): stock assessment review committee (SARC) consensus summary of assessments. Northeast Fish. Sci. Cent. Ref. Doc. 95-08. $221 \mathrm{pp}$.

NEFSC. 1998. 27th northeast regional stock assessment workshop (27th SAW): stock assessment review committee (SARC) consensus summary of assessments. Northeast Fish. Sci. Cent. Ref. Doc. 98-15.

NEFSC. 2000. 31st northeast regional stock assessment workshop (31st SAW): stock assessment review committee (SARC) consensus summary of assessments. Northeast Fish. Sci. Cent. Ref. Doc. 00-15. $400 \mathrm{pp}$.

NEFSC. 2004. 38th northeast regional stock assessment workshop (38th SAW): stock assessment review committee (SARC) consensus summary of assessments. Northeast Fish. Sci. Cent. Ref. Doc. 00-15. 246 pp.

Powell, E. N. \& H. C. Cummins. 1985. Are molluscan maximum life spans determined by long-term cycles in benthic communities? Oecologia 67:177-182.

Ragnarsson, S. A. \& G. G. Thórarinsdóttir. 2002. Abundance of ocean quahog, Arctica islandica, assessed by underwater photography and a hydraulic dredge. J. Shellfish Res. 21:673-676.

Ropes, J. W. \& A. Jearld, Jr. 1987. Age determination of ocean bivalves. In: R. C. Summerfelt \& G. E. Hall, editors. The age and growth of fish. Ames, Iowa: Iowa State Univ. Press. pp. 517-530.

Ropes, J. W., S. A. Murawski \& F. M. Serchuk. 1984. Size, age, sexual maturity, and sex ratio in ocean quahogs, Arctica islandica Linné, off Long Island, New York. Fish. Bull. 82:253-266.

Rowell, T. W., D. R. Chaisson \& J. T. McLane. 1990. Size and age of sexual maturity and annual gametogenic cycle in the ocean quahog, Arctica islandica (Linnaeus, 1767), from coastal waters in Nova Scotia, Canada. J. Shellfish Res. 9:195-203.

Sager, G. \& R. Sammler. 1983. Mathematical investigations into the longevity of the ocean quahog Arctica islandica (Mollusca: Bivalvia). Int. Rev. Ges. Hydrobiol. 68:113-120.

Smolowitz, R. J. \& V.E. Nulk. 1982. The design of an electrohydraulic dredge for clam survey. Mar. Fish. Rev. 44(4):1-18.

Thórarinsdóttir, G. G. \& G. Jóhannesson. 1996. Shell length-meat weight relationships of ocean quahog, Arctica islandica (Linnaeus, 1767), from Icelandic waters. J. Shellfish Res. 15:729-733.

Thórarinsdóttir, G. G. \& S. A. Steingrímsson. 2000. Size and age at sexual maturity and sex ratio in ocean quahog, Arctica islandica (Linnaeus, 1767), off northwest Iceland. J. Shellfish Res. 19:943-947.

Weinberg, J. R., T. G. Dahlgren \& K. M. Halanych. 2002. Influence of rising sea temperature on commercial bivalve species of the US Atlantic coast. Am Fish. Soc. Symp. 32:131-140.

Witbaard, R., M. I. Jenness, K. van der Borg \& G. Ganssen. 1994. Verification of annual growth increments in Arctica islandica L. from the North Sea by means of oxygen and carbon isotopes. Neth. J. Sea Res. 33:91-101. 